\title{
Lanthanide Homobimetallic Triple-Stranded Helicates: Insight into the Self-Assembly Mechanism
}

\author{
Mourad Elhabiri, ${ }^{[a]}$ Josef Hamacek, ${ }^{[a]}$ Jean-Claude G. Bünzli, ${ }^{[b]}$ and \\ Anne-Marie Albrecht-Gary*[a]
}

Keywords: Europium / Helicates / Mechanisms / Self-assembly / Supramolecular chemistry

The self-assembly mechanism leading to the exclusive formation of a triple-stranded bimetallic helicate upon reaction of $\mathrm{Eu}^{\mathrm{III}}$ with a ditopic hexadentate ligand $\mathrm{L}$ bearing two carboxylate moieties has been fully elucidated in water for a wide range of $[\mathrm{Eu}]_{\text {tot }} /[\mathrm{L}]_{\text {tot }}$ ratios. Using a fruitful combination of electrospray mass spectrometry, potentiometry, UV/Vis spectrophotometry, luminescence, and ${ }^{1} \mathrm{H}$ NMR spectroscopy, the final product $\mathrm{Eu}_{2} \mathrm{~L}_{3}$ and the intermediate species $\mathrm{EuL}_{2}$ and $\mathrm{Eu}_{2} \mathrm{~L}_{2}$ have been characterised. The presence of terminal carboxylates in L significantly reduces the electrostatic repulsions of the coordination sites in $\mathrm{Eu}_{2} \mathrm{~L}_{2}$ and $\mathrm{Eu}_{2} \mathrm{~L}_{3}$ compared with the corresponding complexes formed with analogous neutral ligands and thus increases the stability of the L-europium(III) complexes. Kinetic investigations carried out with an excess of $\mathrm{L}$ and with an excess of $\mathrm{Eu}^{\mathrm{III}}$, show that the self-assembly proceeds through either $\mathrm{EuL}_{2}$ or $\mathrm{Eu}_{2} \mathrm{~L}$ intermediates depending on the experimental conditions and leads to a pre-organized $\mathrm{Eu}_{2} \mathrm{~L}_{2}$ complex by either a "braiding" or a "keystone" mechanism. In the last step, a fast and efficient wrapping of the third ligand strand leads to the target $\mathrm{Eu}_{2} \mathrm{~L}_{3}$ helicate. The overall process is mainly governed by electrostatic interactions and proceeds via a key double stranded intermediate helicate $\mathrm{Eu}_{2} \mathrm{~L}_{2}$. To the best of our knowledge, as a result of the fine-tuning of the coordination properties of $\mathrm{L}$, we present one of the most efficient and cooperative metal/ligand systems for the spontaneous organization of a bimetallic triple-stranded structure.

(ㄷ) Wiley-VCH Verlag GmbH \& Co. KGaA, 69451 Weinheim, Germany, 2004)

\section{Introduction}

The self-assembly of supramolecular edifices, which was inspired from one of the basic principles in biology, ${ }^{[1]}$ is an appealing approach to the design of novel nanomaterials with predetermined and specific properties. ${ }^{[2]}$ In particular, combining the toolbox of non-covalent interactions with the intriguing chemical and physicochemical properties of transition metal ions allows one to build functional supramolecular architectures via metal-ion assisted self-assembly. ${ }^{[3]}$ This strategy has successfully generated fascinating two and three-dimensional edifices from polytopic ligands, which include rods, ${ }^{[4]}$ grids, ${ }^{[5]}$ cages, ${ }^{[6]}$ helices, ${ }^{[7]}$ ladders, ${ }^{[8]}$ and rings. ${ }^{[9]}$ Initial studies of metallo-supramolecular helicates have mainly involved double- or triplestranded structures containing cations such as $\mathrm{Cu}^{\mathrm{I}}, \mathrm{Ag}^{\mathrm{I}}$, $\mathrm{Cu}^{\mathrm{II}}, \mathrm{Ni}^{\mathrm{II}}, \mathrm{Ga}^{\mathrm{III}}$, or $\mathrm{Fe}^{\mathrm{III}}$ and ligands derived from bipyri-

[a] Laboratoire de Physico-Chimie Bioinorganique, UMR $7509 \mathrm{du}$ CNRS, ECPM, Université Louis Pasteur,

25 rue Becquerel, 67200 Strasbourg, France

Fax: (internat.) +33-3-90242639

E-mail: amalbre@chimie.u-strasbg.fr

[b] Swiss Federal Institute of Technology Lausanne, Institute of Molecular and Biological Chemistry, BCH 1402, 1015 Lausanne, Switzerland E-mail: jean-claude.bunzli@epfl.ch

Supporting information for this article is available on the WWW under http://www.eurjic.org or from the author. dine, terpyridine, or catechol frameworks. ${ }^{[10,11]}$ The specific magnetic and luminescent ${ }^{[12-14]}$ properties of the trivalent lanthanide cations ${ }^{[15]}$ are increasingly being taken advantage of in medical diagnoses ${ }^{[16,17]}$ and therapy ${ }^{[18]}$ as well as in the catalytic cleavage of DNA and RNA. ${ }^{[19]}$ In this context, the synthesis of elaborate polymetallic lanthanide helicates, which are potentially chiral, may contribute to the development of such applications. However, the poor stereochemical preferences and the variable coordination numbers adopted by $\mathrm{Ln}^{\mathrm{III}}$ ions render difficult a reliable molecular programming in solution. In spite of this difficulty, we have demonstrated that a careful ligand design based on the induced fit principle ${ }^{[20]}$ leads to the strict selfassembly of lanthanide-containing triple-stranded helicates in organic media. ${ }^{[21,22]}$ Ditopic pentadentate, hexadentate or nonadentate ligands derived from 2-pyridin-2-yl-1 $H$ benzimidazole are indeed versatile building blocks and can be used to prepare bimetallic $3 \mathrm{~d}-4 \mathrm{f}$ and $4 \mathrm{f}-4 \mathrm{f}$ assemblies, ${ }^{[23]}$ as well as trimetallic $4 \mathrm{f}-4 \mathrm{f}-4 \mathrm{f}$ edifices. ${ }^{[24]}$ Recently, we have also shown that grafting different substituents at the end of the hexadentate ligands results in ditopic hosts able to specifically recognize a pair of lanthanide ions in solution. ${ }^{[25]}$ Bioanalytical and medical applications require water-soluble probes, so that the ditopic ligand $\mathrm{L}$ with two terminal carboxylate moieties was synthesized (Figure 1) and was found to yield highly stable bimetallic helicates 
a)<smiles>[R]c1cccc(-c2nc3cc(Cc4ccc5c(c4)nc(-c4ccccn4)n5[R])ccc3n2[R])n1</smiles>

$\mathrm{L}: \mathrm{R}^{1}=\mathrm{COO}$ $R^{2}=\mathrm{C}_{2} \mathrm{H}_{5}$<smiles>Cc1nc2ccccc2n1C[14CH2]Oc1ccccc1</smiles>

$L^{B}: R^{1}=C(O) N\left(C_{2} H_{5}\right)_{2}$ $\mathrm{R}^{2}=\mathrm{CH}_{3}$

b)

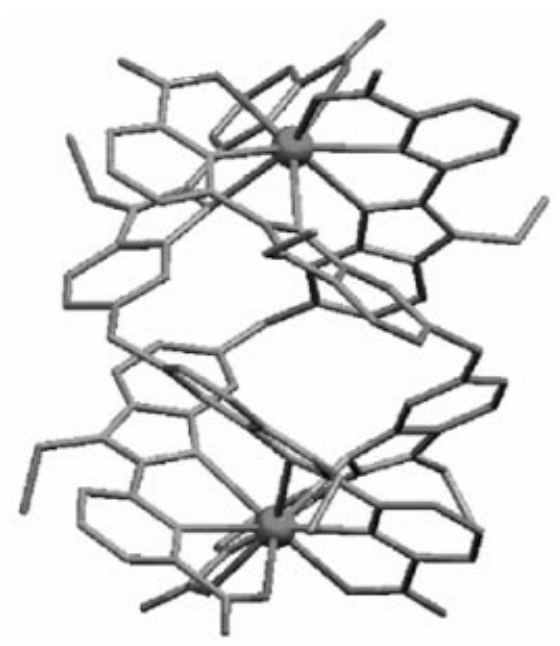

Figure 1. a) Chemical formula of deprotonated transoid ligand L and b) schematic view of the $\mathrm{X}$-ray structure of $\mathrm{Eu}_{2} \mathrm{~L}_{3}{ }^{[26]}$

$\mathrm{Ln}_{2} \mathrm{~L}_{3}$ in water, despite the large hydration enthalpy of the metal ions. ${ }^{[26]}$

The numerous helicates reported so far ${ }^{[10]}$ have been essentially characterised by their molecular structures and, sometimes, by their thermodynamic parameters. Kinetic data, which are essential for deciphering the self-assembly mechanism and, therefore for understanding the recognition process, are extremely scarce. ${ }^{[27-30]}$ As part of our ongoing kinetic investigations of supramolecular edifices with polytopic ligands, dealing with either copper(I) trimetallic double-stranded ${ }^{[29]}$ or lanthanide(III) bimetallic triplestranded ${ }^{[30]}$ helicates in acetonitrile, we present here a detailed physicochemical study of the $\mathrm{Eu}_{2} \mathrm{~L}_{3}$ helicate in aqueous solution. The work is focused on getting a better understanding of the key steps of the self-assembly process. An original combination of potentiometry, absorption and emission spectrophotometry, ES mass spectrometry, and stopped-flow techniques, allowed us to determine both the thermodynamic and kinetic parameters characterising the formation of the bimetallic europium(III) triple-stranded helicate in water.

\section{Results and Discussion}

\section{Ligand Properties}

Detailed interpretation of thermodynamic and kinetic data requires knowledge of the ligand $\mathrm{p} K_{\mathrm{a}}$ values, at least in the $\mathrm{pH}$ range in which the data are collected. Indeed, $\mathrm{p} K_{\mathrm{a}}$ values of the carboxylic acid functions are difficult to determine in view of the extremely poor solubility of the ligand below $\mathrm{pH} 6$ and its precipitation at $\mathrm{pH} 4$. We have therefore investigated the acid-base properties of the ligand in the sole $\mathrm{pH}$ range $10.5-5.8$ by various techniques. Potentiometric titrations of ca. $10^{-3}$ M solutions (Figure S1 in the Supporting Information; see also the footnote on the first page of this article) followed by a statistical treatment of the data ${ }^{[31]}$ yielded the three protonation constants listed in Table 1. The corresponding distribution diagram is presented in Figure S2 (see Supporting Information).

Table 1. Successive protonation constants of ligand L; solvent: water; $T=25.0 \pm 0.2{ }^{\circ} \mathrm{C} ; I=0.1 \mathrm{M}\left(\mathrm{NEt}_{4} \cdot \mathrm{ClO}_{4}\right)$; for the sake of simplicity charges have been omitted

\begin{tabular}{llc}
\hline & Equilibrium & $\log K_{\mathrm{LH}_{\mathrm{n}}} \pm 3 \sigma$ \\
\hline $\mathrm{L}+\mathrm{H}$ & $\stackrel{K_{\mathrm{LH}}}{\longleftarrow} \mathrm{LH}$ & $10.1 \pm 0.1$ \\
$\mathrm{LH}+\mathrm{H}$ & $\stackrel{K_{\mathrm{LH}_{2}}}{\longleftarrow} \mathrm{LH}_{2}$ & \\
& $\stackrel{K_{\mathrm{LH}_{3}}}{\longleftarrow} \mathrm{LH}_{3}$ & \\
$\mathrm{LH}_{2}+\mathrm{H}$ & $\stackrel{6.0 \pm 0.2}{\longleftarrow}$ \\
\hline
\end{tabular}

In order to confirm the first $\mathrm{p} K_{\mathrm{a}}, \mathrm{UV} /$ Visible absorption spectra of the free ligand (see Supporting Information, Figure S3) were recorded in the range $7.38<\mathrm{p}[\mathrm{H}]<11.59$ and a single cumulative protonation constant $\log \beta_{\mathrm{LH}_{2}}=$ $19.8 \pm 0.6$ could be extracted using statistical methods ${ }^{[31]}$ compared with 19.6 obtained by potentiometry.

$\mathrm{L}+\mathrm{nH} \underset{\mathrm{LH}_{\mathrm{n}}}{\longleftarrow} \mathrm{LH}_{\mathrm{n}} \quad$ with $n=2$

We have also taken advantage of the fluorescent properties of the benzimidazole derivatives. ${ }^{[32,33]}$ Decreasing the $\mathrm{p}[\mathrm{H}]$ from 11.43 to 7.59 resulted in a drastic quenching of the ligand-centered fluorescence (Figure 2) and statistical treatment ${ }^{[31]}$ of the data leads to the following protonation constants: $\log K_{\mathrm{LH}}=10.9 \pm 0.7$ and $\log K_{\mathrm{LH}_{2}}=8.7 \pm 0.5$. The re-calculated spectra for $\mathrm{L}, \mathrm{LH}$ and $\mathrm{LH}_{2}$ are presented in Figure S4 (see Supporting Information). 


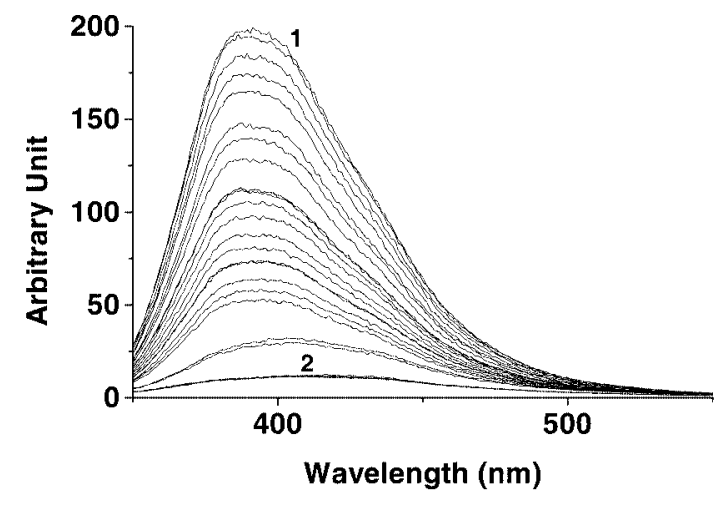

Figure 2. Corrected fluorescence spectra of $\mathrm{L}$ as a function of $\mathrm{p}[\mathrm{H}]$. Solvent: water; $T=25.0 \pm 0.2{ }^{\circ} \mathrm{C} ; I=0.1 \mathrm{M}\left(\mathrm{NEt}_{4} \mathrm{ClO}_{4}\right) ; l=1 \mathrm{~cm}$; $\lambda_{\text {exc }}=308 \mathrm{~nm}$. $[\mathrm{L}]_{\text {tot }}=3.56 \times 10^{-6} \mathrm{M}$; (1) $\mathrm{p}[\mathrm{H}] 11.43$; (2) $\mathrm{p}[\mathrm{H}]$ 7.59. Spectra are not corrected for dilution

Finally, the assignment of the $\mathrm{p} K_{\mathrm{a}}$ values was made on the basis of structural information extracted from ${ }^{1} \mathrm{H}$ and ${ }^{13} \mathrm{C}$ NMR spectra recorded at various $\mathrm{p}[\mathrm{D}]$ values. These data clearly point to both monoprotonated $\mathrm{LH}$ and diprotonated $\mathrm{LH}_{2}$ species retaining $C_{2}$ symmetry in the $\mathrm{p}[\mathrm{D}]$ range 13.00-7.10, indicating that no intramolecular interaction occurs between the two identical subunits of the ditopic strand (Figure 1). This lack of interaction can be further confirmed by the difference between $\log K_{\mathrm{LH}}$ and $\log K_{\mathrm{LH}_{2}}(\Delta \log K=0.6$, Table 1$)$, which is in excellent agreement with a statistical evaluation. ${ }^{[34]}$ NOE effects are consistent with a transoid conformation for the ligand at $\mathrm{p}[\mathrm{D}]=13 \cdot{ }^{[26]}$ When the $\mathrm{p}[\mathrm{D}]$ was decreased from 13.00 to 7.10 , small but significant variations in the chemical shifts of the aromatic protons of the benzimidazole moiety $\left(\mathrm{H}^{4^{\prime}}\right.$, $\mathrm{H}^{6^{\prime}}$, and $\mathrm{H}^{7^{\prime}}$ ) were observed whereas the ${ }^{13} \mathrm{C}$ chemical shifts related to the terminal carboxylates did not vary (Table 2). These NMR spectroscopic data strongly suggest that the first two protonation processes occur at the imidazolyl groups, an assumption confirmed by the absence of a red shift in the absorption and emission spectra in the $\mathrm{p}[\mathrm{H}]$ range 11.4-7.4 (Figure 2 and Figure S3 in the Supporting Information). Such a shift would be expected if the $N$-pyridyl groups were protonated. ${ }^{[35,36]}$

In spite of the converging of the information provided by our measurements, one has to be aware that intra- and intermolecular hydrogen bonding may occur which could modify the above reasoning. For instance, in the case of 2$\left(2{ }^{\prime}\right.$-pyridyl)benzimidazole in hydrochloric acid, ${ }^{15} \mathrm{~N}$ NMR spectroscopic measurements result in only two resonances and are consistent with the presence of fast exchanging resonance structures, one of which having a proton linked to two nitrogen atoms. ${ }^{[37]}$ A similar situation is met for 1,10 phenanthroline which displays one ${ }^{15} \mathrm{~N}$ signal regardless of the solvent, also pointing to the formation of bifurcated hydrogen bonds involving both nitrogen atoms. ${ }^{[38]}$ In our case, formation of a hydrogen bond between the imidazolyl and the pyridine nitrogen atom is feasible and could affect the pyridyl protons, especially $\mathrm{H}^{5}$ (Table 2 and Scheme 1).
Table 2. ${ }^{1} \mathrm{H}$ - and ${ }^{13} \mathrm{C}$-chemical shifts $\delta$ (ppm vs. TMS) as a function of $\mathrm{p}[\mathrm{H}] ; \mathrm{p}[\mathrm{H}]$ values were determined by using $\mathrm{p}[\mathrm{H}]=\mathrm{p}[\mathrm{D}]-$ $0.40 ;{ }^{[88]}$ solvent: $\mathrm{D}_{2} \mathrm{O} ;[\mathrm{L}]_{\mathrm{tot}}=10^{-2} \mathrm{M} ; T=25 \pm 1{ }^{\circ} \mathrm{C}$

\begin{tabular}{|c|c|c|c|c|c|c|c|}
\hline & & & $\delta\left({ }^{1} \mathrm{H}\right)$ & & & & \\
\hline & $\mathrm{H}^{4^{\prime}}$ & $\mathrm{H}^{6^{\prime}}$ & $\mathrm{H}^{7^{\prime}}$ & $\mathrm{H}^{3}$ & $\mathrm{H}^{4}$ & $\mathrm{H}^{5}$ & \\
\hline $\mathrm{p}[\mathrm{H}]=12.6$ & 7.56 & 7.12 & 7.30 & 7.87 & 7.92 & 7.85 & \\
\hline $\mathrm{p}[\mathrm{H}]=10.0$ & 7.54 & 7.08 & 7.26 & 7.86 & 7.91 & 7.82 & \\
\hline $\mathrm{p}[\mathrm{H}]=9.0$ & 7.53 & 7.07 & 7.24 & 7.86 & 7.90 & 7.81 & \\
\hline $\mathrm{p}[\mathrm{H}]=6.7$ & 7.49 & 7.03 & 7.20 & 7.86 & 7.88 & 7.79 & \\
\hline & & & $\delta\left({ }^{13} \mathrm{C}\right)$ & & & & \\
\hline & $C^{4^{\prime}}$ & $C^{6^{\prime}}$ & $\mathrm{C}^{7^{\prime}}$ & $C^{3}$ & $C^{4}$ & $C^{5}$ & $\mathrm{C}=\mathrm{O}$ \\
\hline $\mathrm{p}[\mathrm{H}]=13.1$ & 110.8 & 124.0 & 117.9 & 125.6 & 138.4 & 124.7 & 172.7 \\
\hline $\mathrm{p}[\mathrm{H}]=9.1$ & 110.1 & 124.3 & 117.4 & 123.8 & 137.8 & 125.1 & 172.3 \\
\hline $\mathrm{p}[\mathrm{H}]=7.1$ & 110.1 & 124.4 & 117.4 & 125.1 & 137.9 & 123.9 & 172.4 \\
\hline
\end{tabular}

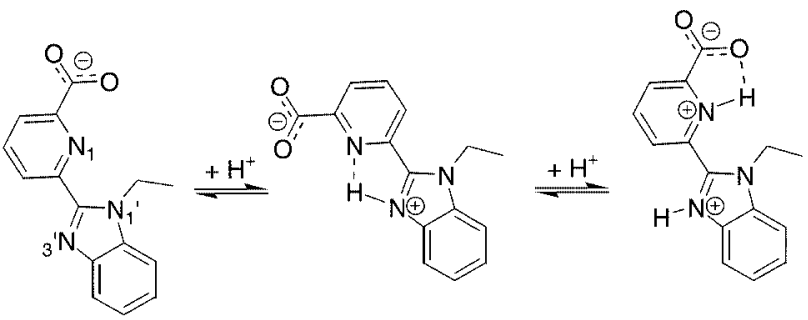

Scheme 1. Potential hydrogen bonding in two protonated subunits of $\mathrm{L}$

The protonation constants $\log K_{\mathrm{LH}}$ and $\log K_{\mathrm{LH}_{2}}$ are at least 4-5 orders of magnitude larger than those reported for benzimidazole $(\log K=5.58)^{[39,40]}$ or 2-(2'-pyridyl)benzimidazole $(\log K=4.41),{ }^{[36]}$ but less than two orders of magnitude smaller than the first protonation constant determined for 1,10-phenanthroline-2,9-dicarboxylic acid in water $\left(\log K_{1}=11.77 \pm 0.08\right) .{ }^{[41]}$ Carboxylic functions in positions 2 and 9 of the phenanthroline indeed induce a drastic increase in the basicity of the $N$-pyridyl atoms compared with phenanthroline $\left(\log K_{1}=4.77\right) \cdot{ }^{[42]} \mathrm{A}$ similar trend can be observed for the ditopic ligand $\mathrm{L}$, and we note that intramolecular hydrogen bonds between $\mathrm{N}\left(3^{\prime}\right)$ and $\mathrm{N}(1)$ would also contribute to increasing $\log K_{\mathrm{LH}}$ and $\log K_{\mathrm{LH}_{2}}$ (Scheme 1). If the third protonation were to take place at $\mathrm{N}(1)$, a large decrease in $K_{\mathrm{LH}_{3}}$ could be expected, due to both statistical effects and hydrogen bonding. The value of $K_{\mathrm{LH}_{3}}$ is about four orders of magnitude lower than $K_{\mathrm{LH}_{2}}$ and could therefore reflect these contributions and be satisfactorily compared with the constant relative to the second protonation of 1,10-phenanthroline-2,9-dicarboxylic acid $\left(\log K_{2}=9.04 \pm 0.14\right) \cdot{ }^{[41]}$ Solubility problems below $\mathrm{p}[\mathrm{H}]$ 5.89 prevented the determination of $K_{\mathrm{LH}_{4}}, K_{\mathrm{LH}_{5}}$, and $K_{\mathrm{LH}_{6}}$. In fact, $K_{\mathrm{LH}_{4}}$ is related to $K_{\mathrm{LH}_{3}}$ in terms of symmetry (L adopting $C_{2}$ symmetry) and statistically should be smaller than the latter by approximately $0.6 \cdot{ }^{[34]}$ Much lower values of $K_{\mathrm{LH}_{5}}$ and $K_{\mathrm{LH}_{6}}$ are expected according to data available in the literature for picolinic $\left(\log K_{2} \approx 1\right)^{[43,44]}$ and 1,10-phenanthroline-2,9-dicarboxylic acids $\left(\log K_{3}=\right.$ $\left.2.37 \pm 0.21^{[41]}\right) .{ }^{[45]}$ In $1.5 \mathrm{M} \mathrm{HClO}_{4}$, slow and irreversible 
degradation of ligand L via a potential de-carboxylation reactions was observed by UV/Visible spectrophotometry (see Supporting Information, Figure S5).

\section{Stoichiometry and Stability of Europium(III) Complexes with $\mathbf{L}$}

The use of electrospray mass spectrometry (ES-MS) to characterize the stoichiometry of metallic complexes in solution is well documented, ${ }^{[10,46]}$ and has been employed by us for this purpose on previous occasions. ${ }^{[21,27-30,47-49]}$ ES-MS measurements were carried out at two different $[\mathrm{Eu}]_{\text {tot }} /[\mathrm{L}]_{\text {tot }}$ ratios (Figure 3 ) and the corresponding spectra clearly indicate the formation of three europium(III) complexes, $\mathrm{Eu}_{2} \mathrm{~L}_{3}, \mathrm{Eu}_{2} \mathrm{~L}_{2}$, and $\mathrm{EuL}_{2}$ (see Supporting Information, Table $\mathrm{S} 1$ ). The peaks of the triple-stranded $\mathrm{Eu}_{2} \mathrm{~L}_{3}$ helicate dominate the spectra, even with an excess of $\mathrm{Eu}^{\mathrm{III}}$. The inner coordination spheres of the minor species $\mathrm{Eu}_{2} \mathrm{~L}_{2}$ and $\mathrm{EuL}_{2}$ are completed with water molecules. Since lanthanide cations possess large solvation energies, ${ }^{[47,48]}$ the ES-MS responses ${ }^{[50]}$ will be drastically decreased for the latter complexes compared with that of the $\mathrm{Eu}_{2} \mathrm{~L}_{3}$ helicate. Loss of neutral $\mathrm{CO}_{2}$ was also observed, as previously reported for amino acid- or peptide-metal complexes in positive $^{[51,52]}$ and in negative modes. ${ }^{[53]}$

To quantify the interaction between $\mathrm{L}$ and $\mathrm{Eu}^{\mathrm{III}}$, we titrated the ligand in water at $\mathrm{p}[\mathrm{H}] 6.15 \pm 0.05$ with eu-

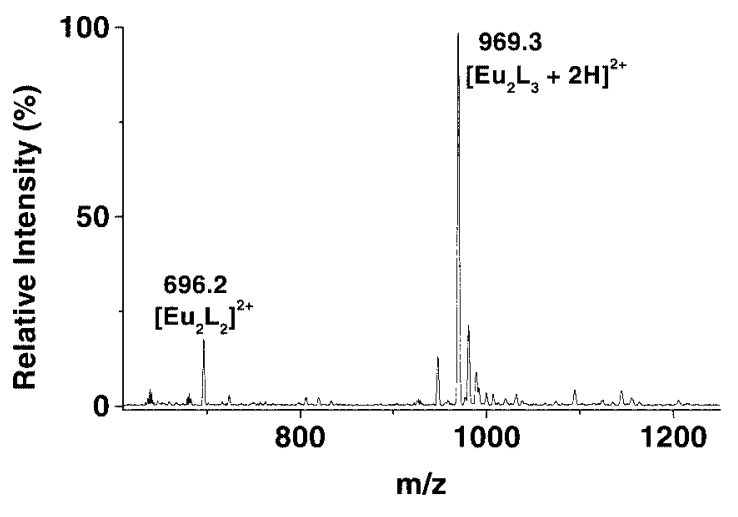

a)

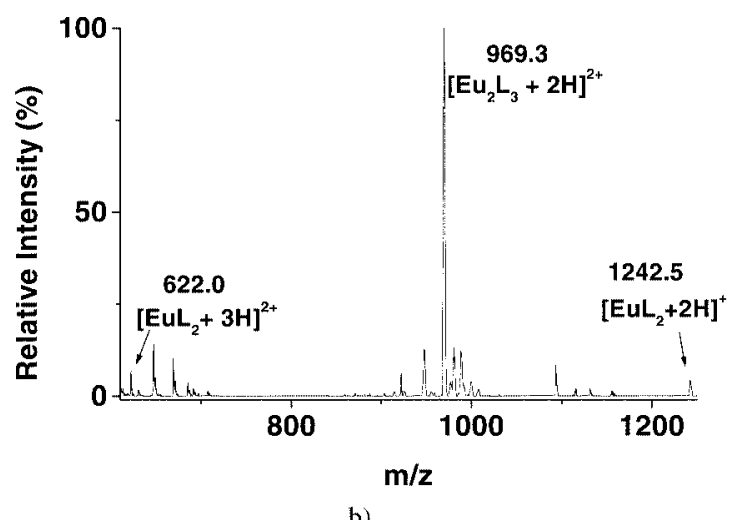

b)

Figure 3. Electrospray mass spectra (a) $[\mathrm{Eu}]_{\mathrm{tot}}=7.96 \times 10^{-4} \mathrm{M}$. $[\mathrm{L}]_{\text {tot }}=4.04 \times 10^{-4} \mathrm{M}$; (b) $[\mathrm{Eu}]_{\text {tot }}=2.05 \times 10^{-4} \mathrm{M}$. $[\mathrm{L}]_{\mathrm{tot}}=7.96$ $\times 10^{-4}$ M. Solvent: $\mathrm{CH}_{3} \mathrm{OH} / \mathrm{H}_{2} \mathrm{O}(80 / 20$ by weight); positive mode; $V_{c}=120 \mathrm{~V}$

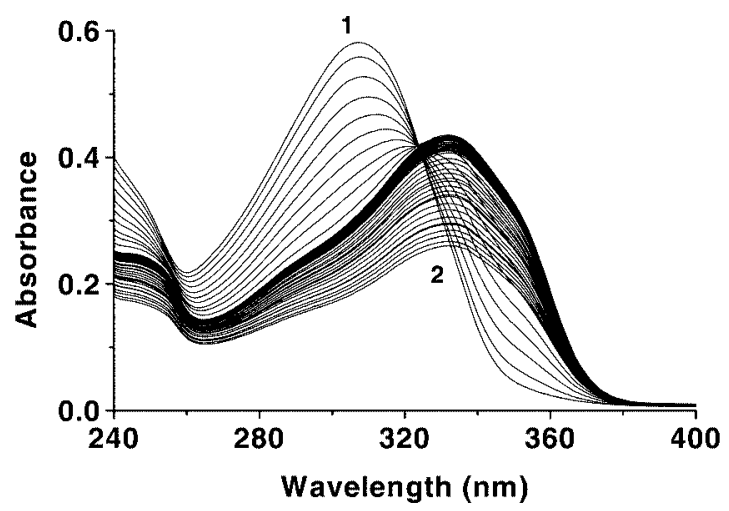

a)

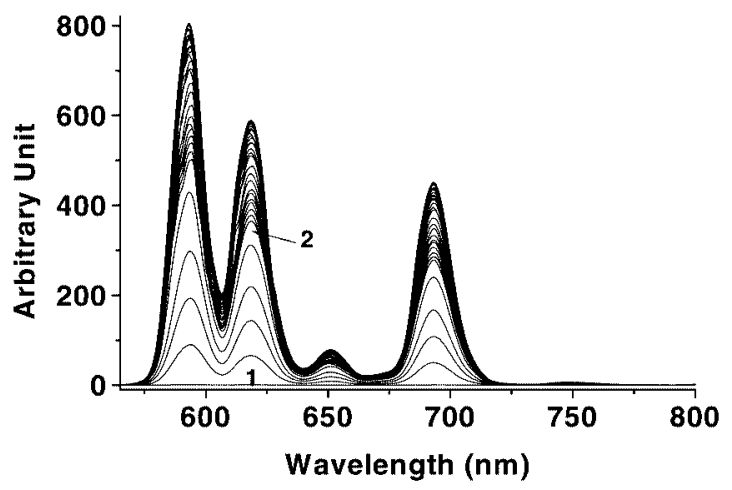

b)

Figure 4. Spectrophotometric titrations of $\mathrm{L}$ versus $\mathrm{Eu}^{\mathrm{III}}$ concentrations. (a) Absorption spectra: $l=2 \mathrm{~cm}$. $[\mathrm{L}]_{\mathrm{tot}}=8.22 \times 10^{-6} \mathrm{M}$; (1) $[\mathrm{Eu}]_{\text {tot }} /[\mathrm{L}]_{\text {tot }}=0$; (2) $[\mathrm{Eu}]_{\text {tot }} /[\mathrm{L}]_{\text {tot }}=23.36$. (b) Gated luminescence spectra; $\lambda_{\text {exc }}=308 \mathrm{~nm} ; t_{d}=0.05 \mathrm{~ms}$; gate time $=1 \mathrm{~ms}$; cycle time $=200 \mathrm{~ms}$. $[\mathrm{L}]_{\mathrm{tot}}=1.64 \times 10^{-6} \mathrm{M} ;(1)[\mathrm{Eu}]_{\mathrm{tot}} /[\mathrm{L}]_{\mathrm{tot}}=0$, (2) $[\mathrm{Eu}]_{\mathrm{tot}} /[\mathrm{L}]_{\mathrm{tot}}=15.37$. Solvent: water; buffer MES $(0.1 \mathrm{M})$; $\mathrm{p}[\mathrm{H}]=6.15 \pm 0.05 ; T=25.0 \pm 0.2{ }^{\circ} \mathrm{C}$

ropium(III) and monitored the changes occurring in solution using both absorption (Figure 4a, and Figure S6 in the Supporting Information) and gated luminescence spectroscopy (Figure 4b).

The formation of the helicate induces a significant red shift to $332 \mathrm{~nm}$ in the ligand $\pi \rightarrow \pi^{*}$ transition band centered at $308 \mathrm{~nm}$ (Figure 4a). Moreover, L was reported to be a fair luminescence sensitizer for europium(III), ${ }^{[26]}$ the absolute quantum yield of the metal-centered luminescence reaching $1.3 \%$ at $\mathrm{p}[\mathrm{H}] \approx 7.0$ with a lifetime of $2.13(2) \mathrm{ms}$. Data were satisfactorily fitted to the simple model represented by Equation (2) and both experiments yielded very similar values (Table 3 ), in agreement with the previously

Table 3. Cumulative stability constants for the $\mathrm{Eu}_{2} \mathrm{~L}_{3}$ helicate; solvent: water; $T=25.0 \pm 0.2{ }^{\circ} \mathrm{C}$

\begin{tabular}{ll}
\hline Titration method & $\log \beta_{\mathrm{Eu}_{2} \mathrm{~L}_{3}} \pm 3 \sigma^{[\mathrm{a}]}$ \\
\hline UV/Vis absorption, direct & $50.6 \pm 2.0$ \\
Gated luminescence, direct & $49.9 \pm 1.3$ \\
${ }^{1} \mathrm{H}$ NMR, competition with DOTA & $52.3 \pm 2.3^{[26]}$
\end{tabular}

[a] The stability constants were calculated ${ }^{[89]}$ from conditional values with the protonation constants given for $\mathrm{L}$ in Table 1 . 
reported one obtained via ${ }^{1} \mathrm{H}$ NMR competitive titrations with various concentrations of DOTA $(1,4,7,10$-tetraazacyclodecane- $N, N^{\prime}, N^{\prime \prime}, N^{\prime \prime \prime}$-tetraacetic acid) in $\mathrm{D}_{2} \mathrm{O} \cdot{ }^{[26]}$

$3 \mathrm{~L}+2 \mathrm{Eu} \stackrel{\beta_{\mathrm{En}, \mathrm{L}_{3}}}{\longleftarrow} \mathrm{Eu}_{2} \mathrm{~L}_{3}$

Spectrophotometric (absorption and luminescence) and NMR spectroscopic data clearly demonstrate that the major species in aqueous solution at $\mathrm{pH} 6.15$ and in a large range of $[\mathrm{Eu}]_{\text {tot }} /[\mathrm{L}]_{\text {tot }}$ ratios is the triple-stranded helicate $\mathrm{Eu}_{2} \mathrm{~L}_{3}$. In addition to this main species ES-MS, which is by far a more sensitive method, indicated the presence of small amounts of $\mathrm{Eu}_{2} \mathrm{~L}_{2}$ with an excess of $\mathrm{Eu}^{\mathrm{III}}$, and of $\mathrm{EuL}_{2}$ with an excess of $\mathrm{L}$. The triple stranded helicate is with no doubt a thermodynamic product and its structure in aqueous solution is the same as that determined by single-crystal X-ray diffraction. ${ }^{[26]}$ Although the $\mathrm{Eu}_{2} \mathrm{~L}_{2}$ species is not seen in the spectrophotometric titrations, 2:2 species have been observed with similar ligands. ${ }^{[21,22]}$ In particular, $\left[\mathrm{Eu}_{2}\left(\mathrm{~L}^{\mathrm{B}}\right)_{2}\right]^{6+}$ $\left(\mathrm{L}^{\mathrm{B}}: \mathrm{R}^{1}=\mathrm{C}(\mathrm{O}) \mathrm{NEt}_{2}\right.$ and $\mathrm{R}^{2}=\mathrm{CH}_{3}$, see Figure 1$)$ adopts a box-like structure in the solid state, in which the ligand strands are arranged "side-by-side" and the two metal are ions connected via hydrogen bonds produced by four water molecules. ${ }^{[22]}$ Therefore, the 2:2 species may also be considered to be a thermodynamic product. The presence of the terminal carboxylate functions of $\mathrm{L}$ could be expected to significantly reduce the electrostatic repulsions of the coordination sites in $\mathrm{Eu}_{2} \mathrm{~L}_{2}$ and $\mathrm{Eu}_{2} \mathrm{~L}_{3}$ by comparison with the corresponding complexes with $\mathrm{L}^{\mathrm{A}}\left(\mathrm{R}^{1}=1\right.$-(3,5-dimethoxybenzyl)- $1 H$-benzimidazole and $\mathrm{R}^{2}=\mathrm{CH}_{3}$, see Figure 1) and $\mathrm{L}^{\mathrm{B}}$ and thus to increase the stability of the L-europium(III) complexes. ${ }^{[54]}$

\section{Formation Kinetics in Excess of Ligand}

Two series of experiments carried out with two different metal concentrations, $[\mathrm{Eu}]_{\mathrm{tot}}=1.06 \times 10^{-6} \mathrm{M}$ and $2.73 \times$ $10^{-6} \mathrm{M}$, allowed us to observe two rate-limiting steps in the second and minute time spans, respectively (see Supporting Information, Figure S7). The corresponding spectrophotometric signals recorded at $350 \mathrm{~nm}$ undergo an increase in absorbance followed by a decrease. The variation of the two corresponding pseudo-first-order rate constants $k_{2, \mathrm{obs}}$ and $k_{3, \text { obs }}\left(\mathrm{s}^{-1}\right)$ versus $[\mathrm{L}]_{\text {tot }}$ (see Supporting Information, Tables $\mathrm{S} 2$ and $\mathrm{S} 3$ ) is presented in Figure 5.

The variation of $k_{2, \text { obs }}$ is in good agreement with a fast pre-equilibrium for the formation of EuL, followed by a slower binding of $\mathrm{L}$ to EuL:

$\mathrm{Eu}+\mathrm{L} \underset{\text { fast }}{\stackrel{K_{\text {ful. }}}{\rightleftarrows}} \mathrm{EuL}$

$\mathrm{EuL}+\mathrm{L} \underset{k_{-2}}{\stackrel{k_{2}}{\rightleftarrows}}$ EuL

The rate law corresponding to the equilibrium according to Equation (4) is expressed by the following Equation (5).
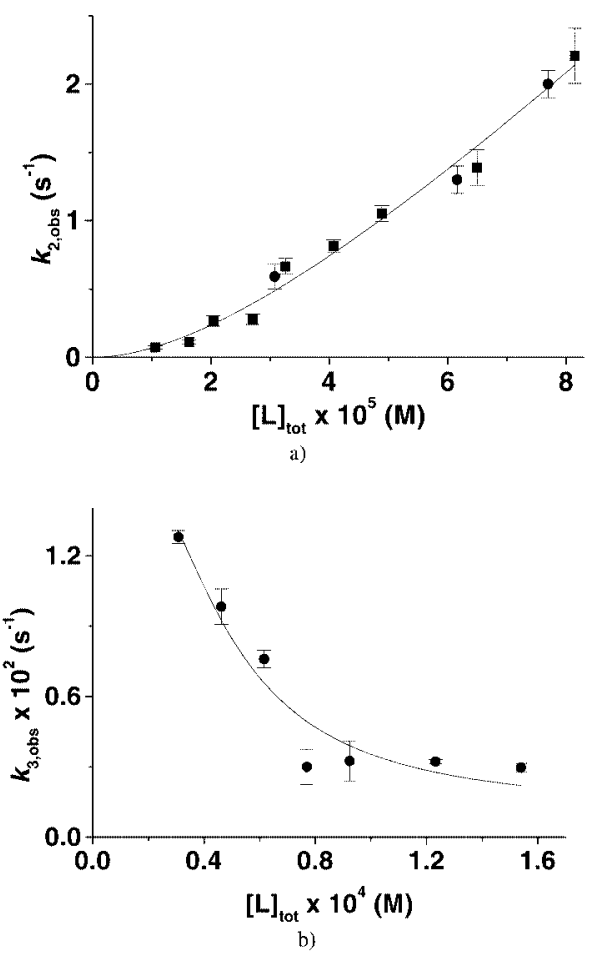

Figure 5. Variation of the pseudo-first order constants $k_{2, \text { obs }}$ (a) and $k_{3 \text {.obs }}$ (b) for the formation of L-europium(III) complexes versus $[\mathrm{L}]_{\text {tot }}$. Solvent: water; $T=25.0 \pm 0.2{ }^{\circ} \mathrm{C} ; \mathrm{p}[\mathrm{H}]=6.15 \pm 0.05$ (MES buffer $0.1 \mathrm{M}) ; \boldsymbol{\square}[\mathrm{Eu}]_{\mathrm{tot}}=1.06 \times 10^{-6} \mathrm{M} ; \bullet[\mathrm{Eu}]_{\mathrm{tot}}=2.73 \times 10^{-6} \mathrm{M}$

$\left.d \mid \mathrm{EuL}_{2}\right] / d \mathrm{t}=k_{2} \times[\mathrm{EuL}] \times[\mathrm{L}]_{\mathrm{tot}}-k_{-2} \times\left[\mathrm{EuL}_{2}\right]$

and leads to Equation (6). ${ }^{[55]}$

$k_{2, \text { obs }}=\frac{k_{2} \times K_{\text {EuL }} \times[\mathrm{L}]_{\text {tot }}^{2}}{1+K_{\text {EuL }} \times[\mathrm{L}]_{10 \mathrm{ft}}}+k_{-2}$

The rate constant $k_{2}$ and the stability constant $K_{\text {EuL }}$ were determined by a non-linear least-squares method ${ }^{[56]}$ (Table 4) but $k_{-2}$ could not be obtained under our experimental conditions.

On the other hand, the variation of $k_{3 \text {,obs }}$ versus $[\mathrm{L}]_{\text {tot }}$ suggests the coordination of a second $\mathrm{Eu}^{\mathrm{III}}$ cation to $\mathrm{EuL}_{2}$ :

$\mathrm{EuL}_{2}+\mathrm{Eu} \underset{k_{-3}}{\stackrel{k_{3}}{\rightleftarrows}} \mathrm{Eu}_{2} \mathrm{~L}_{2}$

The corresponding rate law can be written:

$d\left[\mathrm{Eu}_{2} \mathrm{~L}_{2}\right] / d \mathrm{t}=k_{3} \times\left[\mathrm{EuL}_{2}\right] \times[\mathrm{Eu}]-k_{-3} \times\left[\mathrm{Eu}_{2} \mathrm{~L}_{2}\right]$

Resolution of the differential Equation $(8)^{[55]}$ leads to the following reduced expression, under our experimental conditions:

$k_{3, \mathrm{obs}}=\frac{4 \times k_{3} \times \beta_{\mathrm{EuL}_{2}} \times[\mathrm{L}]_{\mathrm{lot}}^{2} \times[\mathrm{Eu}]_{\mathrm{lul} 1}}{\left(1+K_{\mathrm{EuL}} \times[\mathrm{L}]_{\mathrm{tot}}+\beta_{\mathrm{EuL}_{2}} \times[\mathrm{L}]_{\mathrm{lol}}^{2}\right)^{2}}+k_{-3}$ 
Table 4. Formation mechanism of $\mathrm{Eu}_{2} \mathrm{~L}_{3}$ with an excess of L; solvent: water; $T=25.0 \pm 0.2{ }^{\circ} \mathrm{C}$; $\mathrm{p}[\mathrm{H}]=6.15 \pm 0.05$ (MES buffer $0.1 \mathrm{M}$ ); the errors are given as standard errors ${ }^{[56]}$

\begin{tabular}{|c|c|c|c|c|c|c|}
\hline & Steps & & Hixperimental values & \multicolumn{3}{|c|}{ Calculated values } \\
\hline $\mathbf{E u}+\mathbf{L}$ & $K_{\text {FuI }}$ & EuL & $K_{\text {Eut. }}=(1.9 \pm 0.8) \times 10^{4} \mathrm{M}^{-1}$ & & & \\
\hline $\mathrm{EuL}+\mathrm{L}$ & $\frac{k_{2}}{k_{+2}}$ & $\mathrm{EuL}_{2}$ & $\begin{array}{l}k_{2}=(4.4 \pm 0.9) \times 10^{4} \mathrm{M}^{-1} \mathrm{~s}^{1} \\
\beta \text { EIL } 2-(2.0 \pm 0.7) \times 10^{9} \mathrm{M}^{-2}\end{array}$ & $k_{2}=$ & $\frac{k_{2} \times K_{\mathrm{Ful}}}{\beta_{\mathrm{Eult}_{2}}}$ & $-0.4=0.3 \mathrm{~s}^{-1}$ \\
\hline $\mathrm{Eul}_{2}+\mathrm{Eu}$ & $\underset{k_{-3}}{\stackrel{k_{3}}{\rightleftarrows}}$ & $\mathrm{Eu}_{2} \mathrm{~L}_{2}$ & $\begin{array}{l}k_{3}=(7.0 \pm 0.6) \times 10^{7} \mathrm{M}^{-1} \mathrm{~s}^{-1} \\
k_{3}=(1.1 \pm 0.8) \times 10^{-3} \mathrm{~s}^{-1}\end{array}$ & $K_{\mathrm{Eu} 2 L 2.2}=$ & $\frac{k_{3}}{k_{3}}$ & 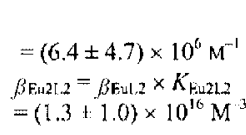 \\
\hline $\mathrm{Eu}_{2} \mathbf{L}_{2}+\mathbf{L}$ & $\frac{k_{4}}{k_{-4}}$ & $\mathrm{Eu}_{2} \mathrm{~L}_{-3}$ & not determined & & & \\
\hline
\end{tabular}

The corresponding rate constants $k_{3}, k_{-3}$ are given in Table 4.

The absorbance at $350 \mathrm{~nm}$ at the end of the third step (Figure S7 in the Supporting Information) is in good agreement, within experimental error, with the sum of the absorption of the excess of free ligand and of the bimetallic triple-stranded helicate $\left(\left[\mathrm{Eu}_{2} \mathrm{~L}_{3}\right]_{\infty}=1 / 2[\mathrm{Eu}]_{\text {tot }}\right)$. This result constitutes a good indication that the last step is faster than the formation of the $\mathrm{Eu}_{2} \mathrm{~L}_{2}$ precursor and that the final step in the formation of $\mathrm{Eu}_{2} \mathrm{~L}_{3}$ involves the addition of a third ligand to $\mathrm{Eu}_{2} \mathrm{~L}_{2}$, in a "braiding" mechanism, as opposed to a "keystone" mechanism in which the second metal ion is added to a pre-organized $\mathrm{EuL}_{3}$ complex. ${ }^{[57]}$

\section{Formation Kinetics with an Excess of Europium(III)}

Kinetic measurements were carried out under pseudofirst order conditions. Two exponential signals were recorded at $332 \mathrm{~nm}$ in the second time range using a stoppedflow technique, whereas an exponential signal was measured in the hour time range on a classical spectrophotometer (Figure 6).

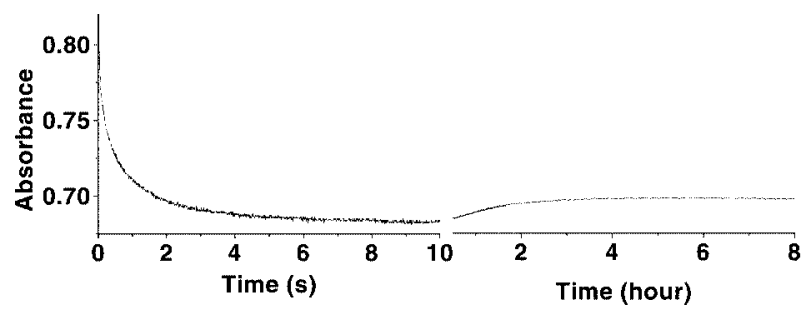

Figure 6. Variation of the absorbance at $332 \mathrm{~nm}$ versus time. Solvent: water; $T=25.0 \pm 0.2{ }^{\circ} \mathrm{C} ; \mathrm{p}[\mathrm{H}]=6.15 \pm 0.05$ (MES buffer 0.1 $\mathrm{M}) ; l=1 \mathrm{~cm} .[\mathrm{L}]_{\mathrm{tot}}=2.55 \times 10^{-5} \mathrm{M},[\mathrm{Eu}]_{\mathrm{tot}}=1.80 \times 10^{-3} \mathrm{M}$

Three corresponding pseudo-first-order rate constants $k_{2}^{\prime}$,obs, $k_{3 \text {,obs }}^{\prime}$, and $k_{4 \text {,obs }}^{\prime}\left(\mathrm{s}^{-1}\right)$ extracted from these data are reported in Table 5 (see also Figure S8 in the Supporting Information).
Table 5. Variation of $k_{2, \mathrm{obs}}^{\prime}, k_{3, \mathrm{obs}}^{\prime}$, and $k_{4, \mathrm{obs}}^{\prime}$ for the formation of L-europium(III) complexes versus $[\mathrm{Eu}]_{\mathrm{tot}}$; solvent: water; $T=$ $25.0 \pm 0.2{ }^{\circ} \mathrm{C} ; \mathrm{p}[\mathrm{H}]=6.15 \pm 0.05($ MES buffer $0.1 \mathrm{M}) ;[\mathrm{L}]_{\text {tot }}=2.55$ $\times 10^{-5} \mathrm{M}$; reported errors are $\pm 3 \sigma$

\begin{tabular}{llll}
\hline $\begin{array}{l}{[\mathrm{Eu}]_{\mathrm{tot}} \times 10^{4}} \\
{[\mathrm{M}]}\end{array}$ & $\begin{array}{l}k^{\prime}{ }_{2, \mathrm{obs}} \\
{\left[\mathrm{s}^{-1}\right]}\end{array}$ & $\begin{array}{l}k^{\prime}{ }_{3, \text { obs }} \\
{\left[\mathrm{s}^{-1}\right]}\end{array}$ & $\begin{array}{l}k^{\prime}{ }_{4, \text { obs }} \times 10^{4} \\
{\left[\mathrm{~s}^{-1}\right]}\end{array}$ \\
\hline 2.57 & $12.9 \pm 2.2$ & $0.99 \pm 0.01$ & $5.3 \pm 0.6$ \\
5.15 & $15.9 \pm 2.5$ & $1.07 \pm 0.03$ & $2.5 \pm 0.3$ \\
7.70 & $16.1 \pm 1.2$ & $1.07 \pm 0.04$ & $2.7 \pm 0.3$ \\
10.30 & $15.1 \pm 2.5$ & $1.08 \pm 0.04$ & $8.2 \pm 0.9$ \\
12.80 & $16.5 \pm 3.6$ & $0.98 \pm 0.02$ & $6.2 \pm 0.9$ \\
15.40 & $16.8 \pm 3.7$ & $0.96 \pm 0.02$ & $1.4 \pm 0.3$ \\
18.00 & $16.2 \pm 2.4$ & $0.86 \pm 0.02$ & $2.4 \pm 0.6$ \\
\hline
\end{tabular}

The pseudo-first-order rate constant $k_{2, o b s}^{\prime}$ increased slightly, but significantly as $[\mathrm{Eu}]_{\mathrm{tot}}$ was increased. A large increase of the spectrophotometric absorption occurred during the dead-time $(\approx 3 \mathrm{~ms})$ of the stopped-flow device and could be attributed to the initial and fast formation of EuL [Equation (3)]. The following equilibria are in satisfactory agreement with these experimental data:

$\mathrm{EuL}+\mathrm{Eu} \underset{k_{-2}^{\prime}}{\stackrel{k_{2}^{\prime}}{\rightleftarrows}} \mathrm{Eu}_{2} \mathrm{~L}$

The rate law corresponding to equilibrium (10) is expressed by:

$d\left[\mathrm{Eu}_{2} \mathrm{~L}\right] / d \mathrm{t}=k_{2}^{\prime} \times[\mathrm{EuL}] \times[\mathrm{Eu}]_{\mathrm{tot}}-k_{-2}^{\prime} \times\left[\mathrm{Eu}_{2} \mathrm{~L}\right]$

and leads to Equation (12): ${ }^{[5]}$

$k_{2, \text { obs }}^{\prime}=\frac{k_{2}^{\prime} \times K_{\mathrm{EuL}} \times[\mathrm{Eu}]_{\mathrm{tot}}^{2}}{1+K_{\mathrm{EuL}} \times[\mathrm{Eu}]_{\mathrm{tot}}}+k_{-2}$ 
Table 6. Formation mechanism of the $\mathrm{Eu}_{2} \mathrm{~L}_{3}$ helicate with an excess of $\mathrm{Eu}^{\mathrm{III}}$; solvent: water; $T=25.0 \pm 0.2{ }^{\circ} \mathrm{C} ; \mathrm{p}[\mathrm{H}]=6.15 \pm 0.05(\mathrm{MES}$ buffer $0.1 \mathrm{M}$ ); the errors are given as standard errors ${ }^{[56]}$

\begin{tabular}{|c|c|c|c|c|c|c|}
\hline & Steps & & Experimental values & \multicolumn{3}{|c|}{ Calculated values } \\
\hline $\mathrm{Eu}+\mathrm{L}$ & $\underset{k_{-1}}{\stackrel{k_{1}}{\longrightarrow}}$ & EuL & $K_{\mathrm{LEII}}=(1.9 \pm 0.5) \times 10^{4} \mathrm{Y}^{-1}$ & & & \\
\hline$E u L+E u$ & $\frac{k_{2}^{\prime}}{k_{-2}^{\prime}}$ & $\mathrm{En}_{2} \mathrm{~L}$ & $\begin{array}{l}k_{2}^{1}=(1.7+0.8) \times 10^{3} \mathrm{M}^{-1} \mathrm{~s}^{-1} \\
k^{\prime}-2=13.8 \pm 0.9 \mathrm{~s}\end{array}$ & $K_{\mathrm{EuZL}}=$ & $\frac{k_{2}^{\prime \prime}}{k_{-2}^{\prime}}$ & $\begin{array}{l}=(1.2 \pm 0.6) \times 10^{2} \mathrm{M} \\
B_{\mathrm{EulL}}=K_{\mathrm{Eu} 2 \mathrm{~L}} \times K_{\mathrm{Eur}} \\
=(2.3 \pm 1.3) \times 10^{6} \mathrm{M}^{2}\end{array}$ \\
\hline $\mathrm{Eat}_{2} \mathrm{~L}+\mathrm{L}$ & $\frac{k_{3}^{\prime}}{\stackrel{3}{k_{3}^{\prime}}}$ & $\mathrm{Eu}_{2} \mathrm{~L}_{2}$ & $k_{3}^{\prime}=(2.2 \pm 0.3) \times 10^{6} \mathrm{M}^{-1} \mathrm{~s}^{-1}$ & $k_{-3}^{\prime}$ & $\frac{k_{3}^{\prime} \times \beta_{\mathrm{Fu}_{\mathrm{u}, \mathrm{L}}}}{\beta_{\mathrm{Eu}, \mathrm{L}_{2}}}$ & $=(3.9 \pm 3.8) \times 10^{4} \mathrm{~s}^{1}$ \\
\hline $\mathrm{Eu}_{2} \mathrm{~L}_{2}+\mathrm{L}$ & $\begin{array}{l}k_{4}^{\prime} \\
k_{-4}^{\prime} \ldots \ldots \rightarrow\end{array}$ & $\mathrm{E}_{2} \mathrm{~L}_{3}$ & $k{ }_{4}=(4 \pm 1) \times 10^{-4} \mathrm{~s}^{-1}$ & $k_{4}^{\prime}=$ & $\frac{k_{-4} \times \beta_{E_{1-1, l_{3}}}}{\beta_{\mathrm{Eu}, 1_{2}}}$ & $=(6.1 \pm 4.9) \times 10^{\prime} \mathrm{M}^{\prime} \mathrm{s}^{1}$ \\
\hline
\end{tabular}

If we consider that under our experimental conditions $K_{\mathrm{EuL}} \times[\mathrm{Eu}]_{\text {tot }}>>1$ :

$k_{2, \mathrm{obs}}^{\prime}=k_{2}^{\prime} \times[\mathrm{Eu}]_{\mathrm{tot}}+k_{-2}^{\prime}$

The values of the rate constants $k_{2}^{\prime}$ and $k^{\prime}{ }_{-2}$ were calculated by a least-squares method ${ }^{[56]}$ and are reported in Table 6.

When $[\mathrm{Eu}]_{\text {tot }}$ is increased, $k^{\prime}{ }_{3 \text {,obs }}$ is decreases (Table 5 and Figure S8b in the Supporting Information), which suggests that the coordination of a second ligand strand to $\mathrm{Eu}_{2} \mathrm{~L}$ takes place and leads to the bimetallic double-stranded species $\mathrm{Eu}_{2} \mathrm{~L}_{2}$ :

$\mathrm{Eu}_{2} \mathrm{~L}+\mathrm{L} \underset{k_{-3}^{\prime}}{\stackrel{k_{3}^{\prime}}{\rightleftarrows}} \mathrm{Eu}_{2} \mathrm{~L}_{2}$

The rate law is then expressed by:

$d\left[\mathrm{Eu}_{2} \mathrm{~L}_{2}\right] / d \mathrm{t}=k_{3}^{\prime} \times\left[\mathrm{Eu}_{2} \mathrm{~L}\right] \times[\mathrm{L}]-k_{-3}^{\prime} \times\left[\mathrm{Eu}_{2} \mathrm{~L}_{2}\right]$

If we assume that equilibrium is reached at the end of the previous steps, we can use the corresponding stability constants to solve the mass balance equation and evaluate [L]:

$[\mathrm{L}]=\frac{[\mathrm{L}]_{\mathrm{tot}}-2 \times\left[\mathrm{Eu}_{2} \mathrm{~L}_{2}\right]}{1+K_{\mathrm{EuL}} \times[\mathrm{Eu}]_{\mathrm{tot}}+\beta_{\mathrm{Ev}_{2} \mathrm{~L}} \times[\mathrm{Eu}]_{\mathrm{tot}}^{2}}$

The new expression of the rate law becomes:

$$
\frac{d\left[\mathrm{Eu}_{2} \mathrm{~L}_{2}\right]}{d \mathrm{t}}=\frac{\left.k_{3}^{\prime} \times \beta_{\mathrm{Eu}_{2} \mathrm{~L}} \times[\mathrm{Eu}]_{\mathrm{tot}}^{2} \times(\mid \mathrm{L}]_{\mathrm{tot}}-2\left[\mathrm{Eu}_{2} \mathrm{~L}_{2}\right]\right)^{2}}{\left(1+K_{\mathrm{EuL}} \times[\mathrm{Eu}]_{\mathrm{tot}}+\beta_{\mathrm{Eu}_{2} \mathrm{~L}} \times\left[\left.\mathrm{Eu}\right|_{\mathrm{tot}} ^{2}\right)^{2}\right.}-k_{-3}^{\prime} \times\left[\mathrm{Eu}_{2} \mathrm{~L}_{2}\right]
$$

The resolution of this differential equation, ${ }^{[55]}$ taking our experimental conditions into account, gives the reduced equation:

$$
k_{3, \mathrm{ohs}}^{\prime}=\frac{4 \times k_{3}^{\prime} \times \beta_{\mathrm{Eu}_{2} \mathrm{~L}} \times[\mathrm{L}]_{\mathrm{fot}} \times[\mathrm{Eu}]_{101}^{2}}{\left(1+K_{\mathrm{EuL}} \times[\mathrm{Eu}]_{\mathrm{tor}}+\beta_{\mathrm{Eu}_{2} \mathrm{~L}} \times[\mathrm{Eu}]_{\mathrm{tot}}^{2}\right)^{2}}+k_{-3}^{\prime}
$$

Statistical processing ${ }^{[56]}$ of the kinetic data allows estimation of $k_{3}^{\prime}, K_{\mathrm{EuL}}$ and $\beta_{\mathrm{Eu}_{2} \mathrm{~L}}$ (Table 6), but not of $k^{\prime}{ }_{-3}$. It is noteworthy that the absorbance at the end of this step (Figure 6) corresponds to the absorption at $332 \mathrm{~nm}$ of the bimetallic triple-stranded helicate $\mathrm{Eu}_{2} \mathrm{~L}_{3}$ (see Supporting Information, Figure S6). This is a sound indication that the formation of $\mathrm{Eu}_{2} \mathrm{~L}_{2}$ is followed by the fast addition of a third ligand strand leading to the final thermodynamically stable helicate $\mathrm{Eu}_{2} \mathrm{~L}_{3}$ :

$\mathrm{Eu}_{2} \mathrm{~L}_{2}+\mathrm{L} \underset{\text { fast }}{\stackrel{k_{4}^{\prime}}{\longrightarrow}} \mathrm{Eu}_{2} \mathrm{~L}_{3}$

A decrease of more than four orders of magnitude was observed for $k_{4 \text {,obs }}^{\prime}$ compared with $k_{3 \text {,obs }}^{\prime}$ (Table 5), but $k^{\prime}{ }_{4, \text { obs }}$ did not vary significantly with $[\mathrm{Eu}]_{\text {tot }}$ (see Supporting Information, Figure S8c). These data strongly suggest a slow release of $\mathrm{L}$ from $\mathrm{Eu}_{2} \mathrm{~L}_{3}$ which was rapidly formed in the previous step:

$\mathrm{Eu}_{2} \mathrm{~L}_{3} \stackrel{k_{-4}^{\prime}}{\longrightarrow} \mathrm{Eu}_{2} \mathrm{~L}_{2}+\mathrm{L}$

The corresponding rate law can now be expressed by the following relationship:

$-d\left[\mathrm{Eu}_{2} \mathrm{~L}_{3}\right] / d \mathrm{t}=k^{\prime}{ }_{-4} \times\left[\mathrm{Eu}_{2} \mathrm{~L}_{3}\right]$

with:

$k_{4, \mathrm{obs}}^{\prime}=k^{\prime}-4$

We will now discuss the overall self-assembly mechanism of the bimetallic triple-stranded helicate $\mathrm{Eu}_{2} \mathrm{~L}_{3}$ presented in 


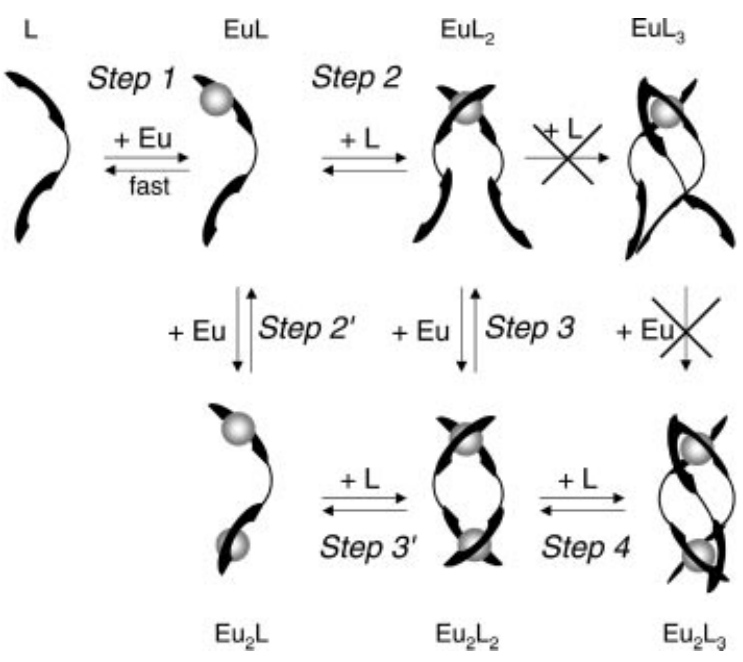

Figure 7. Schematic representation of the self-assembly mechanism of $\mathrm{Eu}_{2} \mathrm{~L}_{3}$

Figure 7. The initial and final steps are independent of the stoichiometric ratio $[\mathrm{Eu}]_{\mathrm{tot}} /[\mathrm{L}]_{\mathrm{tot}}$. In contrast, the intermediate steps depend on whether the kinetics were measured in the presence of an excess of ligand or metal.

Since the water exchange rates of $\mathrm{Ln}^{\mathrm{III}}$ ions are large, ${ }^{[58]}$ slow complex formation is related to the ligand properties. ${ }^{[59-61]}$ The ditopic molecule $\mathrm{L}$ was designed for the fine-tuning of the $\mathrm{Ln}^{\mathrm{III}}$ coordination sphere, with a short methylenic spacer to prevent self-folding. At $\mathrm{p}[\mathrm{H}]=$ $6.15, \mathrm{LH}_{2}$, the major species, possesses one proton on each imidazolyl group. If they are stabilized by hydrogen bonds as shown in Scheme 1, the tridentate subunits of $\mathrm{L}$ adopt a cisoid conformation (Scheme 1) which is preferable to a coordination of $\mathrm{Eu}^{\mathrm{III}}$ limited by the exchange rate of the first water molecule on the lanthanide cation. ${ }^{[58,62]}$ Using the water exchange rate constant $k_{\text {ex }}$ determined by ${ }^{17} \mathrm{O}$ NMR spectroscopy for $\mathrm{Eu}^{\mathrm{III}}\left(5 \times 10^{8} \mathrm{~s}^{-1}\right),{ }^{[58,62]}$ we calculated an outer-sphere stability constant ${ }^{[63,64]} K_{\mathrm{os}}=0.16 \mathrm{M}^{-1}$ for a triple charged cation/neutral ligand system. Under these conditions, the formation rate constant for EuL can be estimated ${ }^{[65]}$ as $k_{1}=K_{\mathrm{os}} \times k_{\mathrm{ex}}=8 \times 10^{7} \mathrm{M}^{-1} \times \mathrm{s}^{-1}$. This value is similar to the literature data reported for the formation of anthranilate- $\mathrm{Eu}^{\mathrm{III}}\left(1.05 \times 10^{8} \mathrm{M}^{-1} \times\right.$ $\left.\mathrm{s}^{-1}\right),{ }^{[66,67]}$ picolinate- $\mathrm{La}^{\mathrm{III}}\left(4.9 \times 10^{8} \mathrm{M}^{-1} \times \mathrm{s}^{-1}\right)$ or picolinate-Dy ${ }^{\mathrm{III}}\left(1.5 \times 10^{8} \mathrm{M}^{-1} \times \mathrm{s}^{-1}\right)^{[68,69]}$ complexes at various temperatures and ionic strengths in water. The formation mechanism of EuL is at odds with the one determined for the $\mathrm{EuL}^{\mathrm{A}}$ analogue, for which conformational changes lead to a slower binding rate constant and to an increased inertness. ${ }^{[30]}$ The stability constant $K_{\mathrm{EuL}}=(1.8 \pm 0.9) \times 10^{4} \mathrm{M}^{-1}$, calculated from the variation of the initial absorbance $A_{0}$ versus $[\mathrm{Eu}]_{\mathrm{tot}}$ in the experiments with an excess of metal (Figure 6 and Figure S9 in the Supporting Information), is in excellent agreement with the values given in Tables 4 and 6. Comparing this constant with the one obtained for the complex with the bidentate picolinate ligand $\left(K_{1}=1.06 \times\right.$ $\left.10^{4} \mathrm{M}^{-1}\right)^{[70]}$ gives a good indication of a partial binding to $\mathrm{Eu}^{\mathrm{III}}$ by one of the tridentate subunits in L. The dissociation rate constant $k_{-1}=k_{1} / K_{\mathrm{EuL}}$ can then be estimated to be ca. $4 \times 10^{3} \mathrm{~s}^{-1}$. EuL is indeed a labile species as was observed, for instance, for the anthranilate-Eu ${ }^{\mathrm{III}}$ complex $\left(3.3 \times 10^{4} \mathrm{~s}^{-1}\right){ }^{[66,67]}$ Step 1 can therefore be considered as being a fast pre-equilibrium in the formation process of the target $\mathrm{Eu}_{2} \mathrm{~L}_{3}$.

With an excess of L, Step 2 implies the binding of a second ligand strand to EuL, leading to the more stable complex $\mathrm{EuL}_{2}$. The bimolecular rate constant $k_{2}$ (Table 4) is about four orders of magnitude lower than $k_{1}$. The electrostatic repulsions between the terminal carboxylate groups of the ligands probably induce conformational rearrangements which drastically slow down the coordination of $\mathrm{L}$ to EuL. The strong negative interactions between the ligands will prevent even more efficiently the formation of $\mathrm{EuL}_{3}$. The addition of a second $\mathrm{Eu}^{\mathrm{III}}$ cation to $\mathrm{EuL}_{2}$ proceeds in Step 3 and leads to a very inert complex $\mathrm{Eu}_{2} \mathrm{~L}_{2}$ for which either the release of a ligand $\left(k_{-3} \approx 10^{-3} \mathrm{~s}^{-1}\right)$ or of a cation $\left(k^{\prime}{ }_{-3} \approx 10^{-4} \mathrm{~s}^{-1}\right)$ is dramatically slow. Since $\mathrm{Eu}_{2} \mathrm{~L}_{2}$ is a minor species, detected by ES-MS but neither by spectrophotometry nor by ${ }^{1} \mathrm{H}$ NMR, its stability constant could only be calculated from the rate constants (Table 4).

With an excess of $\mathrm{Eu}^{\mathrm{III}}$, the binding of a second cation (Step 2') leads to the formation of $\mathrm{Eu}_{2} \mathrm{~L}$. Assuming a dissociative Eigen-Wilkins ${ }^{[65]}$ mechanism and using the Fuoss equation, ${ }^{[63]}$ a formation rate constant equal to $5 \times 10^{3} \mathrm{M}^{-1}$ $\times \mathrm{s}^{-1}$ can be calculated, in excellent agreement with the measured rate constant $k_{2}^{\prime}$ (Table 6). Therefore, the binding of a second $\mathrm{Eu}^{\mathrm{III}}$ cation does not involve any structural rearrangement, but is mainly governed by the de-solvation of the entering cation and by intramolecular electrostatic repulsions. The latter induce a sizeable negative cooperative $\operatorname{effect}^{[27,34]}$ as demonstrated by the ratio $K_{\mathrm{Eu}_{2} \mathrm{~L}} / K_{\mathrm{EuL}} \approx$ $10^{-2}-10^{-3}$. Step $3^{\prime}$ is related to the formation of a doublestranded bimetallic "pre-helicate" from $\mathrm{Eu}_{2} \mathrm{~L}$. The approach of a second ligand is favored because coordination of the first ligand strand labilises the solvation sphere of the two cations and reduces the charge on the two binding sites. The estimation, via $\beta_{\mathrm{Eu}_{2} \mathrm{~L}_{2}}$ (Tables 4 and 6 ), of $k_{-3}^{\prime}\left(\approx 10^{-4}\right.$ $\mathrm{s}^{-1}$ ) provides information on the inertness of $\mathrm{Eu}_{2} \mathrm{~L}_{2}$. A "side-by-side" arrangement, as already reported in the solid state for a closely related ligand ${ }^{[22]}$ with two europium(III) cations, cannot explain an inert edifice in which the interactions between the two lanthanide ions are drastically reduced, perhaps by a "braided" structure (Figure S10, see Supporting Information).

Step 4 corresponds to the fast wrapping of the third strand around $\mathrm{Eu}_{2} \mathrm{~L}_{2}$. The kinetic behavior in Step 4 is dominated by the slow solvolysis of the bimetallic triplestranded helicate. The rate constant $k_{-4}$ listed in Table 6 is within the range of data reported for the dissociation of various $\mathrm{Ln}^{\mathrm{III}}$-polyaminocarboxylate complexes $\left(10^{-6} \mathrm{~s}^{-1}<\right.$ $\left.k<10^{-3} \mathrm{~s}^{-1}\right){ }^{[71]}$ This could also be in line with the X-ray structure of $\mathrm{Eu}_{2} \mathrm{~L}_{3}$, in which two slightly different types of molecules were found, showing that an increase in the solvation of the carboxylates induces a lengthening of $\mathrm{Eu}^{\mathrm{III}}-\mathrm{O}$ distances. ${ }^{[26]}$ It is noteworthy that the self-assembly mechanism of $\mathrm{Eu}_{2} \mathrm{~L}_{3}$ does not exhibit any slow rearrangement from a precursor species, as previously reported by us for 
a tri-cuprous double-stranded helicate. ${ }^{[29]}$ The situation is summarized in Figure 8 which displays the calculated timedependences of the concentrations of the various $\mathrm{Eu}^{\mathrm{III}}$-containing species formed during the self-assembly process for a stoichiometric $[\mathrm{Eu}]_{\text {tot }} /[\mathrm{L}]_{\text {tot }}$ ratio of 0.67 . The formation of the unique species $\mathrm{Eu}_{2} \mathrm{~L}_{3}$ clearly occurs via the "braiding" of two ligand stands around the first Eu ${ }^{\text {III }}$ cation followed by the "keystone" addition of a second $\mathrm{Eu}^{\mathrm{III}}$ ion and a fast wrapping of the third ligand around $\mathrm{Eu}_{2} \mathrm{~L}_{2}$, the latter never being significantly accumulated.

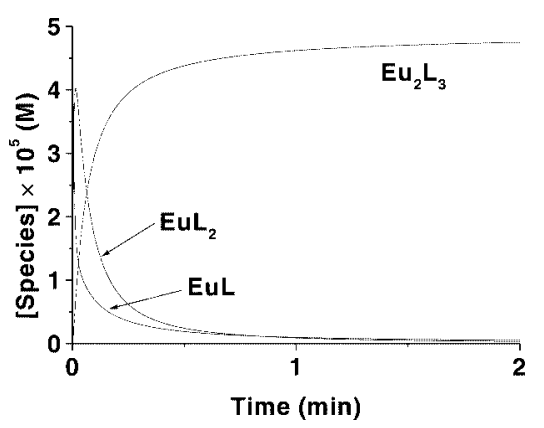

Figure 8. Calculated time dependence of the concentrations of the $\mathrm{Eu}^{\mathrm{III}}$ complexes formed using the rate constants given in Tables 4 and $6 \cdot{ }^{[31]}$ Solvent: water; $T=25.0 \pm 0.2{ }^{\circ} \mathrm{C} ; \mathrm{p}[\mathrm{H}]=6.15 \pm 0.05$ (MES buffer $0.1 \mathrm{M})$. $[\mathrm{L}]_{\mathrm{tot}}=1.5 \times 10^{-4} \mathrm{M} ;[\mathrm{Eu}]_{\mathrm{tot}} /[\mathrm{L}]_{\mathrm{tot}}=0.67$

\section{Conclusion}

A fruitful combination of potentiometry, absorption and emission spectrophotometry, ${ }^{1} \mathrm{H}$ and ${ }^{13} \mathrm{C}$ NMR spectroscopy, and electrospray mass spectrometry allowed us to fully characterize the formation mechanism of a europiumcontaining triple-stranded $\mathrm{Eu}_{2} \mathrm{~L}_{3}$ helicate with a hexadentate ditopic ligand. The self-assembly process implies a key bimetallic double-stranded species $\mathrm{Eu}_{2} \mathrm{~L}_{2}$. This species is very inert towards the release of either a ligand or a cation, but reacts very rapidly with an additional ligand strand to yield the final triple-stranded helicate. This kinetic behavior points to the $\mathrm{Eu}_{2} \mathrm{~L}_{2}$ intermediate probably adopting a structure different from the "side-by-side" arrangement observed for $\mathrm{Eu}_{2}\left(\mathrm{~L}^{\mathrm{B}}\right)_{2}$ in the solid state. ${ }^{[22]}$ Indeed the formation of a 2:2 helical structure at this stage will decrease the steric hindrance and, moreover, the presence of negatively charged terminal carboxylate groups obviously contributes to prevent the formation a labile "side-by-side"[30,57] species. This is in contrast to the formation mechanism of $\mathrm{Eu}_{2}\left(\mathrm{~L}^{\mathrm{A}}\right)_{3}$ for which we propose the formation of a labile intermediate $\mathrm{Eu}_{2}\left(\mathrm{~L}^{\mathrm{A}}\right)_{2} \cdot{ }^{[30]} \mathrm{As}$ far as we can tell, the increased inertness of the key intermediate is the main reason why the rate constant of the last step in the self-assembly process of $\mathrm{Eu}_{2} \mathrm{~L}_{3}$ is $10^{5}$ times larger than $\mathrm{Eu}_{2}\left(\mathrm{~L}^{\mathrm{A}}\right)_{3}$. Moreover, the addition of the successive ligand strands leads to a strong diminishing of the electrostatic interactions between the two coordination sites. These two features, which are reflected by the very low equilibrium concentrations of the intermediates, are probably of importance to "cooperatively" drive a fast and efficient self-assembly of the target triple-stranded di-europium(III) helicate.

In conclusion, the hexadentate ditopic ligand $\mathrm{L}$ leads to one of the most efficient cation/ligand systems for the selfassembly of a bimetallic triple-stranded helicate in water. This is mainly due to the simultaneous presence of a short spacer and of the one negative charge borne by each extremity.

\section{Experimental Section}

Starting Materials and Solvents: $\mathrm{L}$ was synthesized according to a previously published procedure. ${ }^{[26]} \mathrm{Eu}\left(\mathrm{ClO}_{4}\right)_{3} \cdot n \mathrm{H}_{2} \mathrm{O}$ was prepared from the oxide (Rhône-Poulenc, $99.99 \%$ ) in the usual way. ${ }^{[72]}$

CAUTION! Perchlorate salts combined with organic ligands are potentially explosive and should be handled in small quantities and with adequate precautions. ${ }^{[73]}$

Distilled water was further purified by passing through a mixed bed of ion-exchanger (Bioblock Scientific R3-83002, M3-83006) and activated carbon (Bioblock Scientific ORC-83005). Spectrophotometric grade methanol (Merck, p.a.) and water were de-oxygenated using $\mathrm{CO}_{2}$ - and $\mathrm{O}_{2}$-free argon (Sigma Oxiclear cartridge). All stock solutions were prepared using an AG 245 Mettler Toledo analytical balance (precision $0.01 \mathrm{mg}$ ).

Electrospray Mass Spectrometric Measurements: ES mass spectra were recorded on an HP 1100 mass spectrometer (Agilent Technologies, Palo Alto, CA, USA, formerly Hewlett-Packard Company Analytical Products Group). ES-MS was conducted in the positive ion mode. Scanning was performed from $\mathrm{m} / \mathrm{z}=200$ to 1500 and the sampling cone voltage $\left(V_{c}\right)$ was set at $120 \mathrm{~V}$. For electrospray ionization, the drying gas was heated at $250{ }^{\circ} \mathrm{C}$ and its flow set at $3 \mathrm{~L} / \mathrm{min}$, the nebuliser pressure was 10 p.s.i. and the capillary voltage $4 \mathrm{kV}$. Solutions containing ligand L $\left(7.96 \times 10^{-4}, 4.04 \times 10^{-4}\right.$, $\left.2.02 \times 10^{-5} \mathrm{M}\right)$ and various equivalents of $\mathrm{Eu}^{\mathrm{III}}$ were prepared in $\mathrm{CH}_{3} \mathrm{OH} / \mathrm{H}_{2} \mathrm{O}$ (80:20 by weight). They were injected into the mass spectrometer source with a syringe pump (Harvard type PHD 2000, Harvard Apparatus Inc., South Natick, MA, USA) at a flow rate of $2 \mu \mathrm{L} / \mathrm{min}$.

Potentiometric Titrations: The potentiometric titration of $\mathrm{L}$ $\left(1.036 \cdot 10^{-3} \mathrm{M}\right)$ was performed using an automatic titrator system DMS 716 Titrino (Metrohm) with a combined glass electrode (Metrohm 6.0234.500, Long Life) filled with $0.1 \mathrm{~m}$ aqueous $\mathrm{NaCl}$ and connected to a microcomputer. The ionic strength was fixed at $I=$ $0.1 \mathrm{M}$ with tetraethylammonium perchlorate (Fluka, puriss.). The combined glass electrode was calibrated as a hydrogen concentration probe by titrating known amounts of $\mathrm{HClO}_{4}\left(9.997 \times 10^{-2}\right.$ M) with $\mathrm{CO}_{2}$-free $\mathrm{NMe}_{4} \mathrm{OH}$ solutions $\left(1.040 \times 10^{-1} \mathrm{M}\right)$. ${ }^{[74]}$ The cell was thermostatted at $25.0 \pm 0.2{ }^{\circ} \mathrm{C}$ by the flow of a Haake FJ thermostat. A stream of argon, pre-saturated with water vapour was passed over the surface of the solution. The potentiometric data (about 160 points collected over the $\mathrm{pH}$ range 5.9-11.0) were refined with the Hyperquad $2000^{[75]}$ program which uses non-linear least-squares methods. ${ }^{[76]}$ Potentiometric data points were weighted by a formula allowing greater $\mathrm{pH}$ errors in the region of an endpoint than elsewhere. The weighting factor $W_{i}$ is defined as the reciprocal of the estimated variance of measurements: $W_{i}=1 / \sigma_{i}^{2}=$ $1 /\left[\sigma_{\mathrm{E}}^{2}+(\delta E / \delta V)^{2} \sigma_{\mathrm{V}}^{2}\right]$ where $\sigma_{\mathrm{E}}^{2}$ and $\sigma_{\mathrm{V}}^{2}$ are the estimated variances of the potential and volume readings, respectively. The con- 
stants were refined by minimizing the error-square sum, $U$, of the potentials shown below:

$$
U=\sum^{N} W_{i}\left(E_{\mathrm{obs}, i}-E_{\mathrm{cal}_{i}, i}\right)^{2}
$$

Three titrations were treated either as single sets or as separated entities, for each system, without significant variation in the values of the determined constants. The quality of fit was judged by the values of the sample standard deviation, $S$, and the goodness of fit, $\chi^{2}$, (Pearson's test). At $\sigma_{\mathrm{E}}=0.1 \mathrm{mV}\left(0.0023 \sigma_{\mathrm{pH}}\right)$ and $\sigma_{\mathrm{V}}=$ $0.005 \mathrm{~mL}$, the values of $S$ in different sets of titrations were between 0.9 and 1.1, and $\chi^{2}$ was below 12.6. The scatter of residuals versus $\mathrm{pH}$ was reasonably random, without any significant systematic trends, thus indicating a good fit of the experimental data. The successive protonation constants were calculated from the cumulative constants determined with the program. The uncertainties in the $\log K$ values correspond to the added standard deviations in the cumulative constants. The distribution curves of the protonated species of L as a function of $\mathrm{pH}$ (Figure S2, see Supporting Information) were calculated using the Haltafall program. ${ }^{[77]}$

Potentiometric and UV/Visible Titrations: A stock solution of $\mathrm{L}$ $\left(8.91 \times 10^{-5} \mathrm{M}\right)$ was prepared by quantitative dissolution of a solid sample in deionised water and the ionic strength was adjusted to $0.1 \mathrm{M}$ with $\mathrm{NEt}_{4} \mathrm{ClO}_{4}$ (Fluka, puriss). $100 \mathrm{~mL}$ of this solution were introduced into a jacketed cell (Metrohm) maintained at 25.0 \pm 0.2 ${ }^{\circ} \mathrm{C}$ (Haake FJ thermostat). The free hydrogen ion concentration was measured with a combined glass electrode (Metrohm 6.0234.500, Long Life) and a Tacussel Isis 20,000 millivoltmeter. The $\mathrm{Ag} / \mathrm{AgCl}$ reference electrode was filled with $\mathrm{NaCl}(0.01 \mathrm{M}$, Fluka, p.a.) and $\mathrm{NaClO}_{4}(0.09$ M, Fluka, p.a). Standardization of the millivoltmeter and verification of the linearity $(3.00<\mathrm{p}[\mathrm{H}]$ $<9.00$ ) of the electrode were performed using commercial buffers (Merck, Titrisol) according to classical methods. ${ }^{[78]}$ The initial $\mathrm{p}[\mathrm{H}]$ was adjusted to 11.59 with $\mathrm{NMe}_{4} \mathrm{OH}$ (Merck, $10 \mathrm{wt} . \%$ solution in water), and the titration of the free ligand $(7.38<\mathrm{p}[\mathrm{H}]<11.59)$ was then carried out by addition of known volumes of $1.69 \times 10^{-2}$ м perchloric acid (Prolabo, normapur, 70\% min) with an Eppendorf microburette. $\mathrm{HClO}_{4}$ solution (Prolabo, normapur, 70\% min) was titrated with $\mathrm{NaOH}\left(10^{-1} \mathrm{M}\right.$, Carlo Erba, Titrisol Normex) using phenolphthalein (Prolabo, purum) as an indicator and prepared just before use. An aliquot $(1 \mathrm{~mL})$ was taken after each addition of acid, and simultaneous $\mathrm{p}[\mathrm{H}]$ and UV/Visible spectra $(230-400 \mathrm{~nm})$ were recorded. Spectrophotometric measurements were made using Hellma quartz optical cells $(0.2 \mathrm{~cm})$ on a Kontron Uvikon 941 spectrophotometer maintained at $25.0 \pm 0.2{ }^{\circ} \mathrm{C}$ (Haake NB 22 thermostat).

UV/Visible Titrations: To probe the coordination properties of $\mathrm{L}$ with $\mathrm{Eu}^{\mathrm{III}}$, a solution of ligand $\mathrm{L}\left(8.22 \times 10^{-6} \mathrm{M}\right)$ at $\mathrm{p}[\mathrm{H}]=$ $6.15 \pm 0.05[0.1 \mathrm{M}, 2$-morpholinoethanesulfonic acid (MES), Fluka, microselect, $99.5 \%$ ] was prepared. Europium(III) solutions were prepared immediately before use from deionised water saturated with argon. The solutions were acidified to $\mathrm{p}[\mathrm{H}]<4$ with $\mathrm{H}_{2} \mathrm{SO}_{4}$ (Carlo Erba Reagenti, 96\%) before complexometric titration to avoid hydroxide precipitation. Standardized $\mathrm{Na}_{2} \mathrm{H}_{2}$ EDTA solution (Titriplex ${ }^{\circledR}$ III, Merck) in ammonium acetate (Prolabo, rectapur) buffered medium was used with xylene orange as an indicator. ${ }^{[79]}$ The spectrophotometric titration of $\mathrm{L}$ with $\mathrm{Eu}^{\mathrm{III}}$ was carried out in a Hellma quartz optical cell $(2 \mathrm{~cm})$. Microvolumes of a concentrated buffered $(0.1$ м MES, $\mathrm{p}[\mathrm{H}]=6.15 \pm 0.05)$ solution of europium(III) $\left(4.24 \times 10^{-4} \mathrm{M}\right)$ were added to $4 \mathrm{~mL}$ of the stock ligand solution (the $[\mathrm{Eu}]_{\text {tot }} /[\mathrm{L}]_{\text {tot }}$ ratio varied from 0 to 23.36 ). Special care was taken to ensure that complete equilibration was attained. The corresponding UV/Visible spectra were recorded from $230 \mathrm{~nm}$ to $500 \mathrm{~nm}$ on a Kontron Uvikon 941 spectrophotometer maintained at $25.0 \pm 0.2{ }^{\circ} \mathrm{C}$ by the flow of a Haake NB 22 thermostat.

Potentiometric and Fluorescence Titrations: A stock solution of $\mathrm{L}$ $\left(3.56 \times 10^{-6} \mathrm{M}, I=0.1 \mathrm{M} \mathrm{NEt}_{4} \mathrm{ClO}_{4}\right.$, Fluka, puriss) was prepared by quantitative dissolution of a solid sample and $100 \mathrm{~mL}$ were introduced into a jacketed cell (Metrohm) maintained at 25.0 \pm 0.2 ${ }^{\circ} \mathrm{C}$ by the flow of a Haake FJ thermostat. The initial $\mathrm{p}[\mathrm{H}]$ was adjusted to 11.43 with $\mathrm{NMe}_{4} \mathrm{OH}$ (Merck, 10 wt.\% solution in water), and the titration of $\mathrm{L}(7.59<\mathrm{p}[\mathrm{H}]<11.43)$ was carried out by addition of known volumes of $1.69 \times 10^{-2} \mathrm{M}$ perchloric acid (Prolabo, normapur, 70\% min) with an Eppendorf microburette. An aliquot $(2 \mathrm{~mL})$ was taken after each addition of acid, and simultaneous $\mathrm{p}[\mathrm{H}]$ and fluorescence emission spectra were recorded $(350-550 \mathrm{~nm})$ with Hellma quartz optical cells $(1 \mathrm{~cm})$ on a Perkin-Elmer LS-50B instrument maintained at $25.0 \pm 0.2{ }^{\circ} \mathrm{C}$ by the flow of a Haake FJ thermostat. The excitation wavelength was $308 \pm 1 \mathrm{~nm}$ and the slit width was set at $4 \mathrm{~nm}$ for both excitation and emission. The source was a pulsed xenon flash lamp with a pulse width at half peak height $<10 \mu$ s and power equivalent to $20 \mathrm{~kW}$.

Luminescence Titrations: Luminescence titrations were carried out on solutions with an absorbance less than 0.1 at wavelengths $\geq \lambda_{\text {exc }}$ in order to avoid any errors due to the inner filter effect. The $\mathrm{p}[\mathrm{H}]$ was maintained at $6.15 \pm 0.05$ by the use of $0.1 \mathrm{M} \mathrm{MES} \mathrm{(Fluka,}$ microselect, 99.5\%) and perchloric acid (Prolabo, normapur, 70\% $\mathrm{min})$. The titration of $\mathrm{L}\left(1.64 \times 10^{-6} \mathrm{M}\right)$ was carried out in a $1 \mathrm{~cm}$ Hellma quartz optical cell by addition of known microvolumes of a buffered solution of $\mathrm{Eu}^{\mathrm{III}}\left(6.55 \times 10^{-5} \mathrm{M}\right)$ with an Eppendorf multipette ${ }^{\circledR}$ plus microburette. The $[\mathrm{Eu}]_{\text {tot }} /[\mathrm{L}]_{\text {tot }}$ ratio was varied from 0 to 15.37. Metal-centered luminescence spectra were recorded from $550 \mathrm{~nm}$ to $800 \mathrm{~nm}$ on a Perkin-Elmer LS-50B instrument at $25.0 \pm 0.2{ }^{\circ} \mathrm{C}$. Gated spectra were obtained using phosphorimeter acquisition, with a delay time of $0.05 \mathrm{~ms}$, a $200 \mathrm{~ms}$ sample window, $1 \mathrm{~ms}$ per flash and 1 flash per point. The slit width was $12.5 \mathrm{~nm}$ for both excitation and emission.

Analysis and Processing of the Spectroscopic Data: The spectrophotometric data were analyzed with both the Letagrop-Spefo ${ }^{[80-82]}$ and Specfit ${ }^{[31]}$ programs which adjust the absorptivities and the stability constants of the species formed at equilibrium. The Letagrop-Spefo program uses the Newton-Raphson algorithm to solve mass balance equations and a pit-mapping method to minimize the errors and determine the best parameter values. Specfit uses factor analysis to reduce the absorbance matrix and to extract the eigenvalues prior to the multiwavelength fit of the reduced data set according to the Marquardt algorithm. ${ }^{[83,84]}$

Kinetics of Formation: All kinetic measurements were performed in water at $\mathrm{p}[\mathrm{H}]=6.15 \pm 0.05(0.1 \mathrm{~m}$ MES buffer $)$ using a stoppedflow spectrophotometer (Applied Photophysic SX-18MV) equipped with a diode array device. The reactants were thermostatted at $25.0 \pm 0.2{ }^{\circ} \mathrm{C}$ (Lauda M12 thermostat) and mixed in a $1 \mathrm{~cm}$ optical cell. The data sets, averaged out of at least three replications, were recorded and analyzed with the commercial software Biokine. ${ }^{[85]}$ This program fits up to three exponential functions to the experimental curves with the Simplex algorithm ${ }^{[86]}$ after initialization with the Padé-Laplace method. ${ }^{[87]}$

The reaction of $\mathrm{L}$ with $\mathrm{Eu}^{\mathrm{III}}$ in excess was followed at $332 \mathrm{~nm}$. Ligand $\mathrm{L}$ concentration was equal to $2.55 \times 10^{-5} \mathrm{M}$ and $\mathrm{Eu}^{\mathrm{III}}$ concentrations were varied from $2.57 \times 10^{-4} \mathrm{M}$ to $2.57 \times 10^{-3} \mathrm{M}$. The reaction of $\mathrm{Eu}^{\mathrm{III}}$ with ligand $\mathrm{L}$ in excess was followed at $350 \mathrm{~nm}$. 
Two sets of experiments were carried out. Eu ${ }^{\mathrm{III}}$ concentration was equal to $1.06 \times 10^{-6} \mathrm{M}$ or, $2.73 \times 10^{-6} \mathrm{M}$ and $\mathrm{L}$ concentrations were varied from $1.06 \times 10^{-5} \mathrm{M}$ to $8.15 \times 10^{-5} \mathrm{M}$ or from $3.08 \times$ $10^{-5} \mathrm{M}$ to $1.54 \times 10^{-4} \mathrm{M}$.

\section{Acknowledgments}

This work was supported by the Centre National de la Recherche Scientifique (CNRS, UMR 7509), by the faculty of Chemistry (Université Louis Pasteur, Strasbourg, France) and the Swiss National Science Foundation. J. Hamacek thanks the European Community for granting him a Marie Curie fellowship. The authors thank Dr. S. Blanc (Université de Pau et des pays de l'Adour, Laboratoire de Chimie Structurale, Pau, France) for stimulating and helpful discussions, Dr A.-S. Chauvin for her help in acquiring the ${ }^{13} \mathrm{C}$ NMR spectroscopic data and Mr. R. Hueber for his skilful assistance in the ES-MS measurements.

[1] J. E. Vaener (Ed.), Self-Assembly Architecture; A. R. Liss, New York, 1988.

[2] [2a] J. M. Lehn, Supramolecular Chemistry: Concepts and Perspectives, VCH, Weinheim, 1995, chapter 9. ${ }^{2 \mathrm{~b}]} \mathrm{D}$. Philp, J. F. Stoddart, Angew. Chem. Int. Ed. Engl. 1996, 35, 1155-1196; Angew. Chem. 1996, 108, 1242-1286. ${ }^{[2 \mathrm{c}]}$ P. N. W. Baxter, Comprehensive Supramolecular Chemistry, Pergamon, Oxford, 1996, chapter 6. ${ }^{[2 \mathrm{~d}]}$ M. Fujita, Comprehensive Supramolecular Chemistry, Pergamon, Oxford, 1996, chapter 7. [2e] F. Vögtle, Supramolecular Chemistry, John Wiley \& Sons, Chichester, 1991. ${ }^{\left[{ }^{2 f}\right]}$ G. M. Whitesides, J. P. Mathias, C. T. Seto, Science 1991, 254, 1312-1319.

${ }^{[3]}{ }^{[3 a]}$ V. G. Machado, P. N. W. Baxter, J. M. Lehn, J. Braz. Chem. Soc. 2001, 12, 431-462. ${ }^{[3 b]}$ J. M. Lehn, Proc. Natl. Acad. Sci. USA 2002, 99, 4763-4768.

${ }^{[4]}{ }^{[4 a]}$ K. Wärnmark, P. N. W. Baxter, J. M. Lehn, Chem. Commun. 1998, 993-994. ${ }^{[4 b]}$ F. Barigelletti, L. Flamigni, G. Calogero, L. Hammarström, J. P. Sauvage, J. P. Collin, Chem. Commun. 1998, 2333-2334.

[5] [5a] I. Weissbuch, P. N. W. Baxter, S. Cohen, H. Cohen, K. Kjaer, P. B. Howes, J. Als-Nielsen, G. S. Hanan, U. S. Schubert, J. M. Lehn, L. Leiserowitz, M. Lahav, J. Am. Chem. Soc. 1998, 120, 4850-4860. ${ }^{[5 b]}$ A. M. Garcia, F. J. Romero-Salguero, D. M. Bassani, J. M. Lehn, G. Baum, D. Fenske, Chem. Eur. J. 1999, 5, 1803-1808. ${ }^{[5 c]}$ P. N. W. Baxter, J. M. Lehn, J. Fischer, M. T. Youinou, Angew. Chem. Int. Ed. Engl. 1994, 33, 2284-2287; Angew. Chem. 1994, 106, 2432-2434.

${ }^{[6]}{ }^{[6 a]}$ K. N. Power, T. L. Hennigar, M. J. Zaworotko, Chem. Commun. 1998, 595-596. ${ }^{[6 b]}$ M. Fujita, S. Y. Yu, T. Kusukawa, H. Funaki, K. Ogura, K. Yamaguchi, Angew. Chem. Int. Ed. 1998, 37, 2082-2085; Angew. Chem. 1998, 110, 2192-2196.

[7] [7a] A. El-ghayouy, A. Harriman, A. De Cian, J. Fischer, R. Ziessel, J. Am. Chem. Soc. 1998, 120, 9973-9974. ${ }^{[7 b]}$ G. Rapenne, B. T. Patterson, J. P. Sauvage, F. R. Keene, Chem. Commun. 1999, 1853-1854. ${ }^{[7 c]}$ G. Baum, E. C. Constable, D. Fenske, C. E. Housecroft, T. Kulke, Chem. Eur. J. 1999, 5, 1862-1873. ${ }^{[7 d]}$ J. M. Lehn, A. Rigault, Angew. Chem. Int. Ed. Engl. 1988, 27, 1095-1097; Angew. Chem. 1988, 100, 1121-1122. ${ }^{[7 \mathrm{e}]}$ M. Yamamoto, M. Takeuchi, S. Shinkai, F. Tani, Y. Naruta, J. Chem. Soc., Perkin Trans. 2 2000, 9-16.

${ }^{[8]}{ }^{[8 a]}$ P. N. W. Baxter, G. S. Hanan, J. M. Lehn, Chem. Commun. 1996, 2019-2020. ${ }^{[8 b]}$ A. M. Garcia, D. M. Bassani, J. M. Lehn, G. Baum, D. Fenske, Chem. Eur. J. 1999, 5, 1234-1238.

[9] [9a] D. P. Funeriu, J. M. Lehn, G. Baum, D. Fenske, Chem. Eur. J. 1997, 3, 99-104. ${ }^{[9 b]}$ J. A. Whiteford, P. J. Stang, S. D. Huang, Inorg. Chem. 1998, 37, 5595-5601. ${ }^{\left[{ }^{\mathrm{c}}\right]}$ B. Hasenknopf, J. M. Lehn, G. Baum, B. O. Kneisel, D. Fenske, Angew. Chem. Int. Ed. Engl. 1996, 35, 1838-1840; Angew. Chem. 1996, 108, 1987-1990.

${ }^{[10]}$ C. Piguet, G. Bernardinelli, G. Hopfgartner, Chem. Rev. 1997, 97, 2005-2062.
[11] M. Albrecht, Chem. Rev. 2001, 101, 3457-3497.

[12] Y. Haas, G. Stein, J. Phys. Chem. 1971, 75, 3668-3677.

[13] [13a] G. Blasse, Phys. Stat. Sol. A 1992, 130, K85-K89. ${ }^{[13 b]}$ J.C. G. Bünzli, P. Froidevaux, J. M. Harrowfield, Inorg. Chem. 1993, 32, 3306-3311. [13c] S. Petoud, T. Glanzmann, J.-C. G. Bünzli, C. Piguet, Q. Xiang, R. P. Thummel, J. Luminesc. 1999, $82,69-79$.

${ }^{[14]}$ N. Sabbatini, S. Perathoner, V. Balzani, B. Alpha, J. M. Lehn, Supramolecular Chemistry (Ed.: V. Balzani), D. Reidel Publishing Co., Dordrecht, 1987.

${ }^{[15]}$ J.-C. G. Bünzli, Lanthanide Probes in Life, Chemical and Earth Sciences: Theory and Practice (Eds.: J.-C. G. Bünzli, G. R. Choppin), Elsevier Science Publ. B. V., Amsterdam, 1989.

${ }^{[16]}$ The Chemistry of Contrast Agents in Medical Magnetic Resonance Imaging (Eds.: A. E. Merbach, E. Tóth), Wiley, London, 2001.

[17] [17a] I. Hemmilä, T. Ståhlberg, P. Mottram, Bioanalytical Applications of Labelling Technologies, Wallac Oy, Turku, 1995. [17b] G. Mathis, in: Rare Earths (Eds.: R. Saez-Puche, P. Caro), Editorial Complutense, Madrid, 1998.

${ }^{[18]}$ J.-C. G. Bünzli, in: Metal Ions in Biological Systems (Eds.: A. Sigel, H. Sigel), Marcel Dekker Inc., New York, 2003, vol. 41, chapter 15 , in press.

[19] [19a] P. Hurst, B. K. Takasaki, J. Chin, J. Am. Chem. Soc. 1996, 118, 9982-9983. [19b] T. C. Bruice, A. Tsubouchi, R. O. Dempey, L. P. Olson, J. Am. Chem. Soc. 1996, 118, 9867-9875. [19c] A. Roigk, R. Hettich, H. J. Schneider, Inorg. Chem. 1998, $37,751-756$

${ }^{[20]}$ D. E. Koshland Jr., Angew. Chem. Int. Ed. Engl. 1994, 33, 2375-2378; Angew. Chem. 1994, 106, 2368-2371.

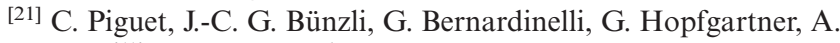
F. Williams, J. Am. Chem. Soc. 1993, 115, 8197-8206.

${ }^{[22]}{ }^{[22 a]}$ N. Martin, J.-C. G. Bünzli, V. McKee, C. Piguet, G. Hopfgartner, Inorg. Chem. 1998, 37, 577-589. ${ }^{[22 b]}$ C. Platas Iglesias, M. Elhabiri, M. Hollenstein, J. C. G. Bünzli, C. Piguet, J. Chem. Soc., Dalton Trans. 2000, 2031-2043. ${ }^{[22 c]}$ R. Tripier, M. Hollenstein, M. Elhabiri, A. S. Chauvin, G. Zucchi, C. Piguet, J. C. G. Bünzli, Helv. Chim. Acta 2002, 85, 1915-1929.

[23] [23a] J.-C. G. Bünzli, C. Piguet, Chem. Rev. 2002, 102,

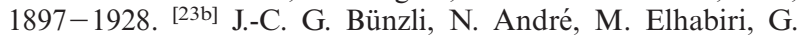
Muller, C. Piguet, J. Alloys Compd. 2000, 303-304, 66-74.

${ }^{[24]}{ }^{[24 a]}$ B. Bocquet, G. Bernardinelli, N. Ouali, S. Floquet, F. Renaud, G. Hopfgartner, C. Piguet, Chem. Commun. 2002, 930-931. [24b] S. Floquet, N. Ouali, B. Bocquet, G. Bernardinelli, D. Imbert, J. C. G. Bünzli, G. Hopfgartner, C. Piguet, Chem. Eur. J. 2003, 9, 1860-1875.

${ }^{[25]}$ N. André, R. Scopelliti, G. Hopfgartner, C. Piguet, J.-C. G. Bünzli, Chem. Commun. 2002, 214-215.

${ }^{[26] ~[26 a] ~ M . ~ E l h a b i r i, ~ R . ~ S c o p e l l i t i, ~ J .-C . ~ G . ~ B u ̈ n z l i, ~ C . ~ P i g u e t, ~ C h e m . ~}$ Commun. 1998, 2347-2348. ${ }^{[26 b]}$ M. Elhabiri, R. Scopelliti, J.C. G. Bünzli, C. Piguet, J. Am. Chem. Soc. 1999, 121, $10747-10762$.

[27] S. Blanc, P. Yakirevitch, E. Leize, M. Meyer, J. Libman, A. Van Dorsselaer, A. M. Albrecht-Gary, A. Shanzer, J. Am. Chem. Soc. 1997, 119, 4934-4944.

${ }^{[28]}$ N. Fatin-Rouge, S. Blanc, E. Leize, A. Van Dorsselaer, P. Baret, J. L. Pierre, A. M. Albrecht-Gary, Inorg. Chem. 2000, 39, $5771-5778$.

${ }^{[29]}$ N. Fatin-Rouge, S. Blanc, A. Pfeil, A. Rigault, A. M. AlbrechtGary, J. M. Lehn, Helv. Chim. Acta 2001, 84, 1694-1711.

${ }^{[30]}$ J. Hamacek, S. Blanc, M. Elhabiri, E. Leize, A. Van Dorsselaer, C. Piguet, A. M. Albrecht-Gary, J. Am. Chem. Soc. 2003, 125, 1541-1550.

[31] [31a] H. Gampp, M. Maeder, C. J. Meyer, A. D. Zuberbühler, Talanta 1985, 32, 95-101. ${ }^{[31 b]}$ F. J. C. Rossotti, H. S. Rossotti, R. J. Whewell, J. Inorg. Nucl. Chem. 1971, 33, 2051-2065. ${ }^{[31 \mathrm{c}]}$ H. Gampp, M. Maeder, C. J. Meyer, A. D. Zuberbühler, Talanta 1985, 32, 257-264. [31d] H. Gampp, M. Maeder, C. J. Meyer, A. D. Zuberbühler, Talanta 1986, 33, 943-951. 
${ }^{\left[{ }^{2}\right]}$ R. G. Brown, N. Entwistle, J. D. Hepworth, K. W. Hodgson, B. May, J. Phys. Chem. 1982, 86, 2418-2420.

${ }^{[33]}$ F. R. Prieto, M. Mosquera, M. Novo, J. Phys. Chem. 1990, 94, 8536-8542.

${ }^{[34]}$ B. Perlemutter-Hayman, Acc. Chem. Res. 1986, 19, 90-96.

${ }^{[35]}$ M. C. Rios Rodriguez, J. C. Penedo, R. J. Willemse, M. Mosquera, F. R. Prieto, J. Phys. Chem. A 1999, 103, 7236-7243.

${ }^{[36]}$ M. Novo, M. Mosquera, F. R. Prieto, Can. J. Chem. 1992, $70,823-827$.

${ }^{[37]}$ N. S. Rao, G. B. Rao, B. N. Murthy, M. M. Das, T. Prabhakar, M. Lalitha, Spectrochim. Acta A 2002, 58, 2737-2757.

${ }^{[38]}$ N. S. Rao, M. M. Das, G. B. Rao, D. Ziessow, Spectrosc. Lett. 1985, 18, 827-836.

[39] L. E. Kapinos, B. Song, H. Sigel, Chem. Eur. J. 1999, 5, 1794-1802.

${ }^{[40]}$ H. Xiao Feng, L. La Sheng, L. Xue Yi, C. Xiao Ming, J. Liang Nian, Z. Zhong Yuan, Inorg. Chim. Acta 1999, 285, 326-331.

${ }^{[41]}$ R. M. Dyson, G. A. Lawrance, H. Mäcke, M. Maeder, Polyhedron 1999, 18, 3243-3251.

[42] S. Yajima, Y. Hasegawa, Bull. Chem. Soc. Jpn. 1998, 71, $2825-2829$.

${ }^{[43]}$ E. Kiss, K. Petrohán, D. Sanna, E. Garribba, G. Micera, T. Kiss, Polyhedron 2000, 19, 55-61.

[44] [44a] R. I. Gelb, J. S. Alper, J. Chem. Eng. Data 1998, 43, 383-385. ${ }^{[44 b]}$ R. W. Green, H. K. Tong, J. Am. Chem. Soc. 1956, 78, 4896-4900.

${ }^{[45]}$ In reference $26 \mathrm{~b}, \mathrm{p} K_{\mathrm{a}}$ data are incorrect. In fact the reported figures (4.42 and 7.7) are $\mathrm{p} K_{\mathrm{b}}$ values and not $\mathrm{p} K_{\mathrm{a}}$ values. Recalculating these data in terms of $\mathrm{p} K_{\mathrm{a}}$ values gives 9.6 and 6.3 , two values in good agreement with those reported in Table 1, given the slightly different experimental conditions.

[46] [46a] G. Hopfgartner, C. Piguet, J. D. Henion, A. F. Williams, Helv. Chim. Acta 1993, 76, 1759-1766. ${ }^{[46 b]}$ G. Hopfgartner, C. Piguet, J. D. Henion, J. Am. Soc., Mass Spectrom. 1994, $5,748-756$.

[47] [47a] C. Piguet, E. Rivara-Minten, G. Hopfgartner, J.-C. G. Bünzli, Helv. Chim. Acta 1995, 78, 1541-1572. [47b] C. Piguet, G. Hopfgartner, A. F. Williams, J.-C. G. Bünzli, J. Chem. Soc., Chem. Commun. 1995, 491-493.

[48] [48a] C. Piguet, J.-C. G. Bünzli, G. Bernardinelli, G. Hopfgartner, S. Petoud, O. Schaad, J. Am. Chem. Soc. 1996, 118, 6681-6697. ${ }^{[48 b]}$ C. Piguet, G. Bernardinelli, J.-C. G. Bünzli, S. Petoud, G. Hopfgartner, J. Chem. Soc., Chem. Commun. 1995, 2575-2577.

[49] [49a] C. Piguet, E. Rivara-Minten, G. Bernardinelli, J.-C. G. Bünzli, G. Hopfgartner, J. Chem. Soc., Dalton Trans. 1997, 421-433. ${ }^{[49 b]}$ G. Bernardinelli, C. Piguet, A. F. Williams, $A n-$ gew. Chem. Intl. Ed. Engl. 1992, 31, 1622-1624; Angew. Chem. 1992, 104, 1626-1628.

${ }^{[50]}\left[{ }^{[50]}\right.$ E. Leize, A. Jaffrezic, A. Van Dorsselaer, J. Mass Spectrom. 1996, 31, 537-544. ${ }^{[50 b]}$ I. I. Stewart, G. Horlick, Anal. Chem. 1994, 66, 3983-3993.

[51] J. A. Leenheer, C. E. Rostad, P. M. Gates, E. T. Furlong, I. Ferrer, Anal. Chem. 2001, 73, 1461-1471.

[52] [52a] C. L. Gatlin, R. D. Rao, F. Turecek, T. Vaisar, Anal. Chem. 1996, 68, 263-270. ${ }^{[52 b]}$ P. Hu, J. A. Loo, J. Am. Chem. Soc. 1995, 117, 11314-11319.

[53] [53a] A. Reiter, J. Adams, H. Zhao, J. Am. Chem. Soc. 1994, 116, 7827-7838. ${ }^{[53 b]}$ P. Hu, M. L. Gross, J. Am. Soc., Mass. Spectrom. 1994, 5, 137-143.

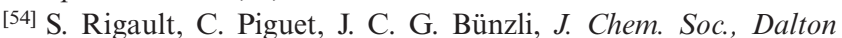
Trans. 2000, 2045-2053.

[55] [55a] K. A. Connors, Chemical Kinetics. The Study of Reaction Rates in Solution, VCH Verlagsgesellschaft, Weinheim, Germany, 1990, chapter 3. ${ }^{[55 b]}$ C. Capellos, B. H. J. Bielski, Kinetic Systems: Mathematical Description of Chemical Kinetics in Solution, Wiley-Interscience, New York, 1972.
${ }^{[56]}$ Microcal $^{\mathrm{TM}}$ Origin ${ }^{\mathrm{TM}}$, Microcal Software, Inc., Northampton, USA

${ }^{[57]}$ L. J. Charbonnière, A. F. Williams, A. Frey, A. E. Merbach, P. Kamalaprija, O. Schaad, J. Am. Chem. Soc. 1997, 119, 2488-2496.

${ }^{[58]}{ }^{\text {[58a] }}$ C. Cossy, L. Helm, A. E. Merbach, Inorg. Chem. 1988, 27, 1973-1979. ${ }^{[58 b]}$ C. Cossy, A. E. Merbach, Pure Appl. Chem. 1988, 60, 1785-1796. ${ }^{[58 c]}$ C. Cossy, L. Helm, A. E. Merbach, Inorg. Chem. 1989, 28, 2699-2703.

${ }^{[59]}$ G. U. Priimov, P. Moore, L. Helm, A. E. Merbach, Inorg. React. Mech. 2001, 3, 1-23.

${ }^{[60]}$ E. Szilágyi, É. Tóth, Z. Kovács, J. Platzek, B. Radüchel, E. Brücher, Inorg. Chim. Acta 2000, 298, 226-234.

${ }^{[61]}$ E. Brücher, D. Sherry, Inorg. Chem. 1990, 29, 1555-1559.

${ }^{[62]}$ L. Helm, A. E. Merbach, Coord. Chem. Rev. 1999, 187, $151-181$.

[63] [63a] R. M. Fuoss, J. Am. Chem. Soc. 1958, 80, 5059-5061. [63b] M. Eigen, Z. Phys. Chem. 1954, 1, 176-200.

${ }^{[64]}{ }^{[64 a]}$ J. E. Prue, J. Chem. Soc. 1965, $7534-7535 .{ }^{[64 b]}$ D. B. Rorabacher, Inorg. Chem. 1966, 5, 1891-1899.

[65] [65a] M. Eigen, R. G. Wilkins, Adv. Chem. Ser. 1965, 49, 55-67. [65b] M. Eigen, K. Tamm, Z. Electrochem. 1962, 66, 93-107. ${ }^{\left[{ }^{65 c]}\right.}$ R. G. Wilkins, Acc. Chem. Res. 1970, 3, 408-416.

[66] [66a] H. B. Silber, J. H. Swinehart, J. Phys. Chem. 1967, 71, 4344-4348. ${ }^{[66 b]}$ H. B. Silber, R. D. Farina, J. H. Swinehart, Inorg. Chem. 1969, 8, 819-824.

[67] Values determined at $T=12.5^{\circ} \mathrm{C}$ and $I=0.2 \mathrm{M}\left(\mathrm{NaClO}_{4}\right)$ using the temperature jump relaxation method.

${ }^{[68]}$ T. E. Eriksen, I. Grenthe, I. Puigdomenech, Inorg. Chim. Acta 1987, 126, 131-135.

[69] Values determined at $T=20^{\circ} \mathrm{C}$ in aqueous solutions containing $0.5 \mathrm{~m}$ tert-butyl alcohol and using the radiation induced $\mathrm{pH}$-jump technique.

${ }^{[70]}$ L. C. Thompson, Inorg. Chem. 1964, 3, 1319-1321.

${ }^{[71]}$ S. Saito, H. Hoshino, T. Yotsuyanagi, Inorg. Chem. 2001, 40, $3819-3823$

[72] J. F. Desreux, Lanthanide Probes in Life, Chemical and Earth Sciences. Theory and Practice (Eds.: J.-C. G. Bünzli, G. R. Choppin), Elsevier Science Publ., B. V., Amsterdam, 1989.

${ }^{[73]}$ K. N. Raymond, Chem. Eng. News 1983, 61, 4.

${ }^{[74]}$ P. Gans, B. O'Sullivan, Talanta 2000, 51, 33-37.

[75] [75a] P. Gans, A. Sabatini, A. Vacca, HYPEROUAD2000: Leeds, U. K., and Florence, Italy. ${ }^{[75 b]}$ P. Gans, A. Sabatini, A. Vacca, Talanta 1996, 43, 1739-1753.

[76] P. Gans, Data Fitting in the Chemical Sciences, John Wiley \& Sons, Chichester, 1992.

${ }^{[77]}$ N. Ingri, W. Kakolowicz, L. G. Sillen, B. Warnqvist, Talanta 1967, 14, 1261-1286.

${ }^{[78]}$ A. E. Martell, R. J. Motekaitis, Determination and Use of Stability Constants, VCH Verlagsgesellschaft, Weinheim, Germany, 1988, chapter 1 .

${ }^{[79]}$ Méthodes d'analyses complexométriques avec les titriplex ${ }^{\circledR}, 3 \mathrm{rd}$ edition, E. Merck Ed., Grafis: Darmstadt, 1992.

${ }^{[80]}$ L. G. Sillen, Acta Chem. Scand. 1964, 18, 1085-1098.

${ }^{[81]}$ L. G. Sillen, B. Warnqvist, Ark. Kemi. 1968, 31, 377-390.

${ }^{[82]}$ J. Havel, Pure Appl. Chem. 1972, 34, 370-383.

${ }^{[83]}$ D. W. Marquardt, J. Soc., Indust. Appl. Math. 1963, 11, $431-441$.

[84] M. Maeder, A. D. Zuberbühler, Anal. Chem. 1990, 62, $2220-2224$

[85] Bio-Logic Company, Ed. Bio-Logic Company, Echirolles, 1991.

${ }^{[86]}$ J. A. Nelder, R. Mead, The Computer Journal 1965, 7 , 308-313.

[87] E. Yeramian, P. Claverie, Nature 1987, 326, 169-174.

${ }^{[88]}$ P. K. Glasoe, F. A. Long, J. Phys. Chem. 1960, 64, 188-190.

${ }^{[89]}$ A. Ringbom, Complexation in Analytical Chemistry, John Wiley \& Sons, Inc., New York, 1963.

Received August 8, 2003

Early View Article

Published Online October 30, 2003 